Prepared in cooperation with the Colorado Water Conservation Board

\title{
Streamflow and Selenium Loads During Synoptic Sampling of the Gunnison River and its Tributaries near Delta, Colorado, November 2015
}

Scientific Investigations Report 2018-5029 



\section{Streamflow and Selenium Loads During Synoptic Sampling of the Gunnison River and its Tributaries near Delta, Colorado, November 2015}

By Michael R. Stevens, Kenneth J. Leib, Judith C. Thomas, Nancy J. Bauch, and Rodney J. Richards

Prepared in cooperation with the Colorado Water Conservation Board

Scientific Investigations Report 2018-5029 


\title{
U.S. Department of the Interior \\ RYAN K. ZINKE, Secretary
}

\author{
U.S. Geological Survey \\ James F. Reilly II, Director
}

U.S. Geological Survey, Reston, Virginia: 2018

For more information on the USGS - the Federal source for science about the Earth, its natural and living resources, natural hazards, and the environment-visit https://www.usgs.gov or call 1-888-ASK-USGS.

For an overview of USGS information products, including maps, imagery, and publications,

visit https://store.usgs.gov.

Any use of trade, firm, or product names is for descriptive purposes only and does not imply endorsement by the U.S. Government.

Although this information product, for the most part, is in the public domain, it also may contain copyrighted materials as noted in the text. Permission to reproduce copyrighted items must be secured from the copyright owner.

Suggested citation:

Stevens, M.R., Leib, K.J., Thomas, J.C., Bauch, N.J., and Richards, R.J., 2018, Streamflow and selenium loads during synoptic sampling of the Gunnison River and its tributaries near Delta, Colorado, November 2015: U.S. Geological Survey Scientific Investigations Report 2018-5029, 17 p., https://doi.org/10.3133/sir20185029.

ISSN 2328-0328 (online) 


\section{Contents}

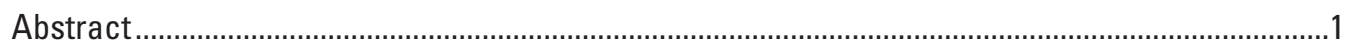

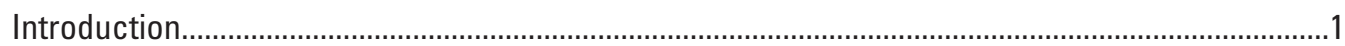

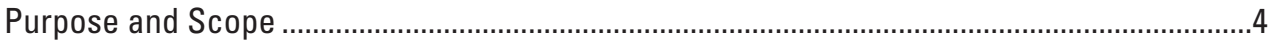

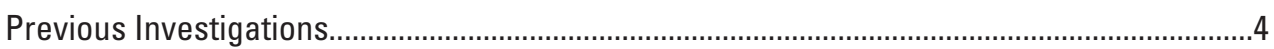

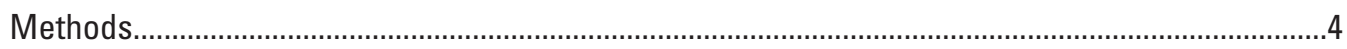

Streamflow Measurement Methods ....................................................................................

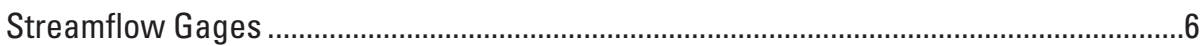

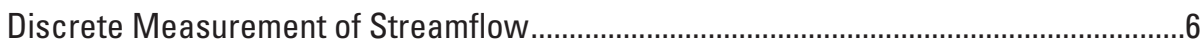

Water-Quality Measurements and Sampling on Main-Stem and Tributary Sites......................7

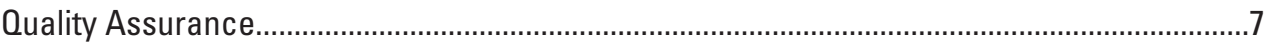

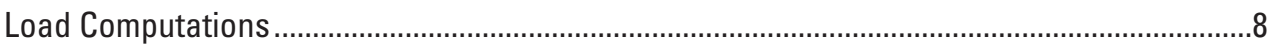

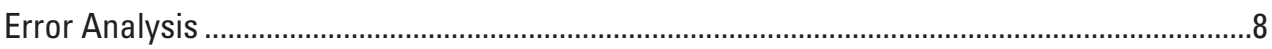

Streamflow and Selenium Loads ......................................................................................

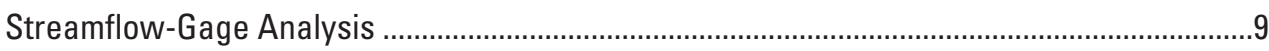

Results of Synoptic Streamflow Analysis .........................................................................11

Results of Synoptic Selenium Concentration and Load Analysis ..........................................12

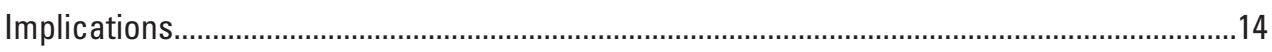

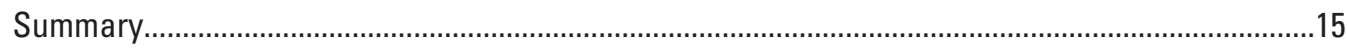

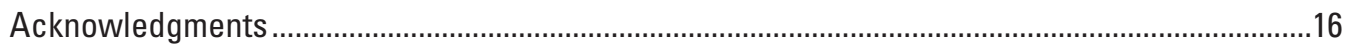

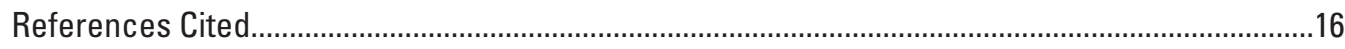

\section{Figures}

1. Map showing contributing areas to the U.S. Geological Survey streamflow gage, Gunnison River near Grand Junction, Colo., used for loading calculations ...

2. Map showing the location of the study reach and sites sampled during the synoptic study, Delta County, Colorado

3. Boxplot showing streamflow gage record comparison of the average 5-day difference in combined streamflows of 09144250 and 09149500 , and the downstream station 09152500 for the 2011 through 2015 water years

4-6. Graphs showing:

4. Main-stem Gunnison River streamflows along cumulative distance along the main-stem Gunnison River with error bars corresponding to accuracy of the streamflow values, and cumulative measured tributary inflows to the main-stem Gunnison River....

5. Dissolved selenium concentrations with error bars for tributaries and the main-stem Gunnison River

6. Main-stem Gunnison River dissolved selenium loads along the main-stem Gunnison River with error bars corresponding to accuracy of the load values, and cumulative measured tributary loads to the main-stem Gunnison River 


\section{Tables}

1. Selenium concentration, streamflow, selenium load, and selenium load error for the synoptic samples collected November 19, 2015, near Delta, Colorado.

2. Selenium concentration, streamflow, selenium load, and selenium load error at additional sites downstream from the synoptic reach, near Delta, Colorado.

\section{Conversion Factors}

U.S. customary units to International System of Units

\begin{tabular}{lcl}
\hline \multicolumn{1}{c}{ Multiply } & By & \multicolumn{1}{c}{ To obtain } \\
\hline & Length & \\
\hline $\begin{array}{l}\text { foot }(\mathrm{ft}) \\
\text { mile }(\mathrm{mi})\end{array}$ & 0.3048 & meter $(\mathrm{m})$ \\
& 1.609 & kilometer $(\mathrm{km})$ \\
\hline \multicolumn{3}{c}{ Volume } \\
\hline cubic foot $\left(\mathrm{ft}^{3}\right)$ & 0.02832 & cubic meter $\left(\mathrm{m}^{3}\right)$ \\
\hline & Flow rate & \\
\hline cubic foot per second $\left(\mathrm{ft}^{3} / \mathrm{s}\right)$ & 0.02832 & cubic meter per second $\left(\mathrm{m}^{3} / \mathrm{s}\right)$ \\
\hline & Mass & \\
\hline pound, avoirdupois $(\mathrm{lb})$ & 0.4536 & kilogram $(\mathrm{kg})$ \\
pounds per day $(\mathrm{lb} / \mathrm{d})$ & 0.454 & kilograms per day $(\mathrm{k} / \mathrm{d})$ \\
\hline
\end{tabular}

Temperature in degrees Celsius $\left({ }^{\circ} \mathrm{C}\right)$ may be converted to degrees Fahrenheit $\left({ }^{\circ} \mathrm{F}\right)$ as

$$
{ }^{\circ} \mathrm{F}=\left(1.8 \times{ }^{\circ} \mathrm{C}\right)+32 \text {. }
$$

Temperature in degrees Fahrenheit $\left({ }^{\circ} \mathrm{F}\right)$ may be converted to degrees Celsius $\left({ }^{\circ} \mathrm{C}\right)$ as ${ }^{\circ} \mathrm{C}=\left({ }^{\circ} \mathrm{F}-32\right) / 1.8$.

\section{Datum}

Vertical coordinate information is referenced to the North American Vertical Datum of 1988 (NAVD 88).

Horizontal coordinate information is referenced to the North American Datum of 1983 (NAD 83). Altitude, as used in this report, refers to distance above the vertical datum. 


\section{Supplemental Information}

Water year-October 1 through September 30, designated by the year in which it ends.

Specific conductance is given in microsiemens per centimeter at 25 degrees Celsius $(\mu \mathrm{S} / \mathrm{cm}$ at $\left.25^{\circ} \mathrm{C}\right)$.

Concentrations of chemical constituents in water are given in either milligrams per liter (mg/L) or micrograms per liter $(\mu \mathrm{g} / \mathrm{L})$.

\section{Abbreviations}

$\begin{array}{ll}\text { ADCP } & \text { Acoustic Doppler Current Profiler } \\ \text { DH } & \text { Depth-integrated handheld } \\ \text { LGRB } & \text { Lower Gunnison River Basin } \\ \text { NWIS } & \text { National Water Information System } \\ \text { Reclamation } & \text { U.S. Bureau of Reclamation } \\ \text { RPD } & \text { Relative Percentage Difference } \\ \text { SD } & \text { Standard Deviation } \\ \text { Se } & \text { selenium } \\ \text { SMP } & \text { Selenium management program } \\ \text { USFWS } & \text { U.S. Fish and Wildlife Service } \\ \text { USGS } & \text { U.S. Geological Survey } \\ \text { WRD } & \text { Water Resources Division } \\ \text { WY } & \text { Water Year }\end{array}$





\title{
Streamflow and Selenium Loads During Synoptic Sampling of the Gunnison River and its Tributaries near Delta, Colorado, November 2015
}

\author{
By Michael R. Stevens, Kenneth J. Leib, Judith C. Thomas, Nancy J. Bauch, and Rodney J. Richards
}

\section{Abstract}

In response to the need for more information about selenium (Se) sources and transport, the U.S. Geological Survey, in cooperation with the Colorado Water Conservation Board, completed a study that characterized Se loads in a reach of the Gunnison River between Delta and Grand Junction, Colo. This report identifies where possible dissolved Se loading is occurring in a study reach in the Lower Gunnison River Basin between Delta and Grand Junction on November 19, 2015.

The combined Se loads from the Gunnison River at Delta (site 3) and the Uncompahgre River at Delta (site 4) were about 95 percent of the load at the furthest downstream main-stem sample location at the Gunnison River below Roubideau Creek near Delta (site 20) (31.6 and 33.4 pounds per day, respectively), indicating that about 5 percent of the total load (1.8 pounds) was potentially contributed from diffuse groundwater inflow. Main-stem streamflow accounting during November 2015 in a downstream direction was not supportive of substantial net gains or losses in the main-stem water balance.

The cumulative load from measured tributary inflows downstream from the Uncompahgre River confluence only amounted to 1.2 pounds of the main-stem loads (1.8 pounds gain) from site 4 to the end of the synoptic reach at site 20 . The remaining 33 percent (about 0.6 pounds) of Se load increase was not accounted for by known tributary inflow. Yet, the small changes in the streamflow mass balance in the same reach does not strongly support a net inflow explanation for the apparent gain in load.

Based on the results of the loading and streamflow analysis, when errors in the loading estimates are considered, there is no conclusive evidence of an appreciable amount of Se load that is unaccounted for in the study reach of the Gunnison River as was originally hypothesized. Differences determined from comparisons of cumulative tributary loads and Gunnison River main-stem loads for this study are within error estimates of the main-stem loads.

\section{Introduction}

In 2013, the U.S. Bureau of Reclamation (Reclamation) established the Selenium Management Program (SMP) for the Lower Gunnison River Basin (LGRB) (fig. 1) (Reclamation, 2014). The SMP formed in response to a Programmatic Biological Opinion issued by the U.S. Fish and Wildlife Service (USFWS), which stated that the recovery of native Colorado fish species (primarily Colorado pikeminnow, Ptychocheilus lucius; and razorback sucker, Xyrauchen texanus) is limited by selenium (Se) concentrations that exceed aquatic standards (USFWS, 2009). The SMP consists of Federal, State, and local agencies as well as local water users and is open to the public. The group seeks to identify and mitigate Se sources to decrease Se levels in endangered fish habitat in the Gunnison River and its tributaries.

Prior to this study, the U.S. Geological Survey (USGS) in cooperation with Reclamation completed a review of dissolved Se data at 18 sites in the LGRB for water years (WY, October 1 through September 30, designated by the year in which it ends) 2011-2014 (Henneberg, 2016). Selenium loading data collected at USGS streamflow gages 09144250, Gunnison River at Delta (site 3, this study, table 1) and 09149500, Uncompahgre River at Delta (site 4), during WYs 2011 to 2014 were summed for all 4 years and compared to the Se load at a downstream, streamflow gage 09152500, Gunnison River near Grand Junction (site 23, fig. 2) for the same 4 years (data from table 2 in Henneberg, 2016). Site 3 (19,500 pounds [lbs] dissolved Se) summed with site 4 (24,800 lbs dissolved $\mathrm{Se}$ ) was equal to $44,300 \mathrm{lbs}$ dissolved Se. When compared to the sum of 4 years of Se loads at site 23 (54,500 lbs dissolved Se), the Gunnison River at sites 3 and 4 (fig. 2) accounted for about 81 percent of the load at site 23 (data from table 2 in Henneberg, 2016). This analysis did not include an assessment of load contributions from surface-water tributaries downstream of sites 3 and 4.

In 2006, Reclamation conducted a study (Reclamation, 2006) investigating the contributing areas to USGS streamflow 
gage 09152500, Gunnison River near Grand Junction (fig. 1). An analysis of total Se loads from 6 contributing areas (CA1 to CA6) in the Gunnison River Basin indicated that a percentage of the total dissolved Se load in surface water at the USGS streamflow gage 09152500, Gunnison River near Grand Junction (site 23, fig. 2) was missing from an Se load mass balance based on samples at 52 sites from 1988 to 1999 . Reclamation (2006) estimated that only about 83 percent of the Se load could be accounted for when combining loads from the six contributing areas, including CA1, when compared to the Se load at site 23 .
As a result of the loading estimates from these studies that indicated a potential missing part of the Se load, the SMP indicated a need for a potential study to investigate a reach of the Gunnison River near Delta, Colo. within CA6 (fig. 1), which was suspected to be a source of Se load, but had not been quantified. Because little agriculture is present downstream from the Gunnison River below Roubideau Creek near Delta (site 20), the reach for a comprehensive tributary mass balance in a proposed study ended at that point on the river (fig. 2). The reach between the confluence of the Gunnison and Uncompahgre Rivers at Delta and Gunnison River near Grand

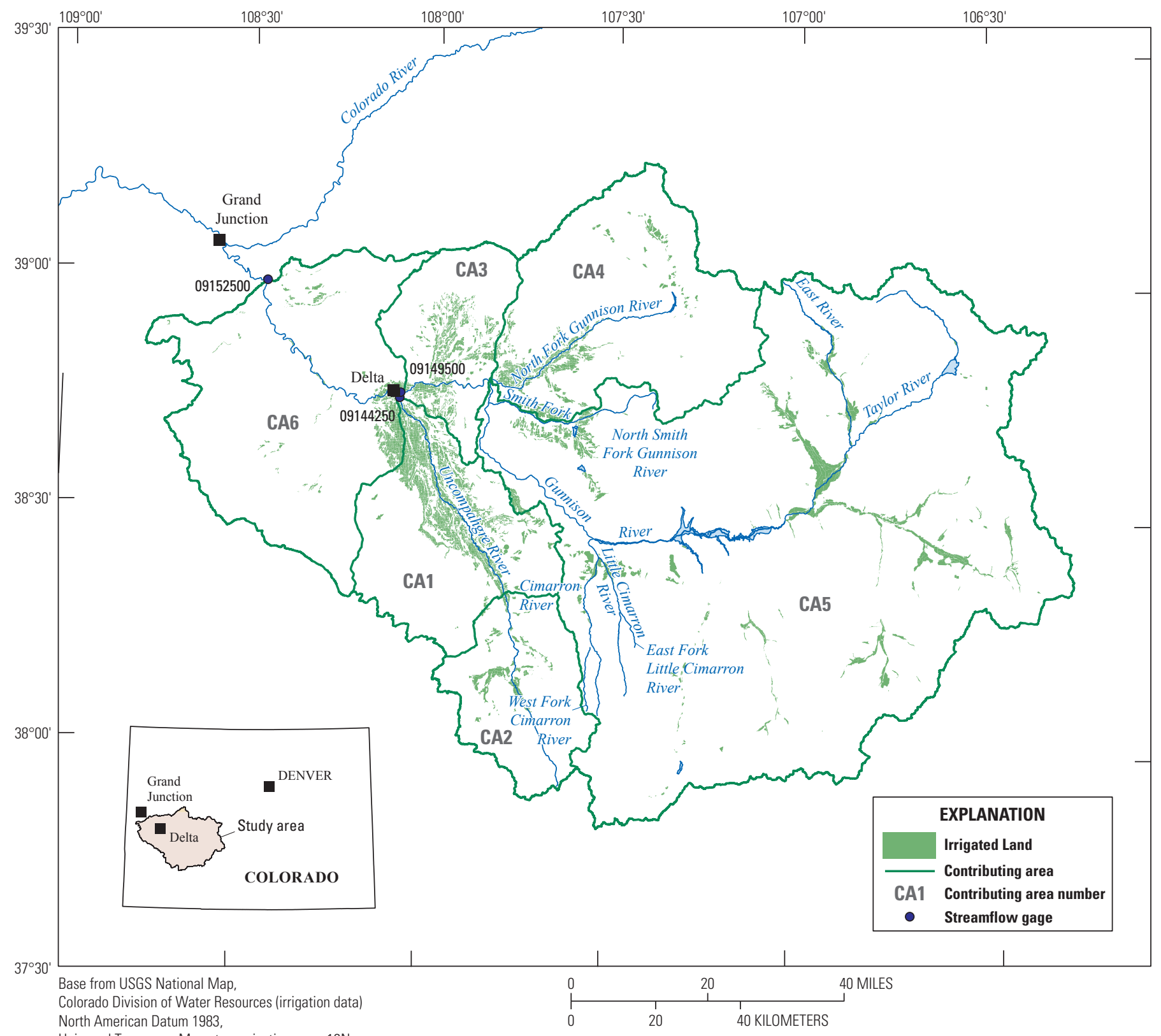

Universal Transverse Mercator projection, zone 13N

Figure 1. Contributing areas to the U.S. Geological Survey streamflow gage, Gunnison River near Grand Junction, Colo. (09152500), used for loading calculations (modified from Bureau of Reclamation, 2006). 


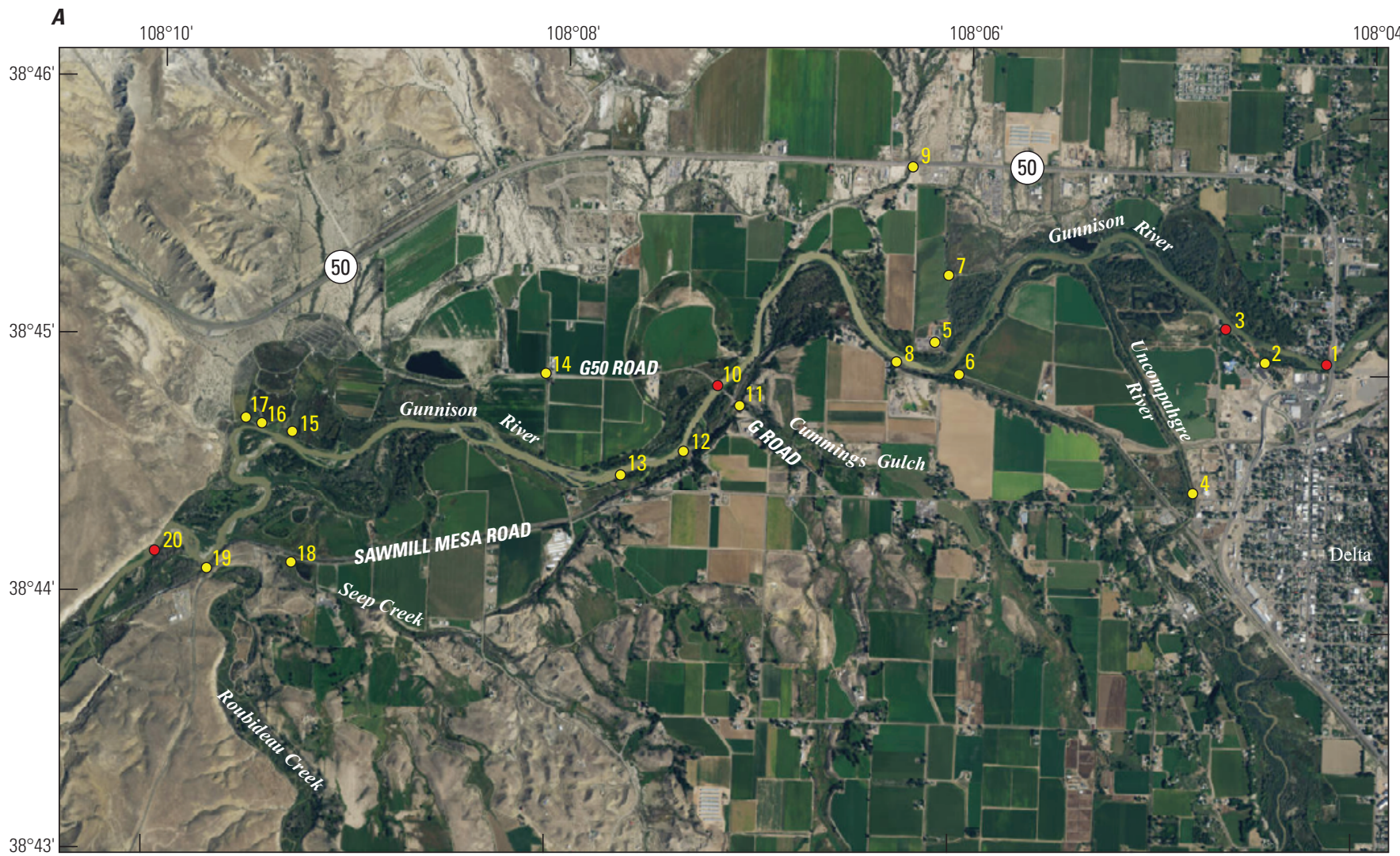

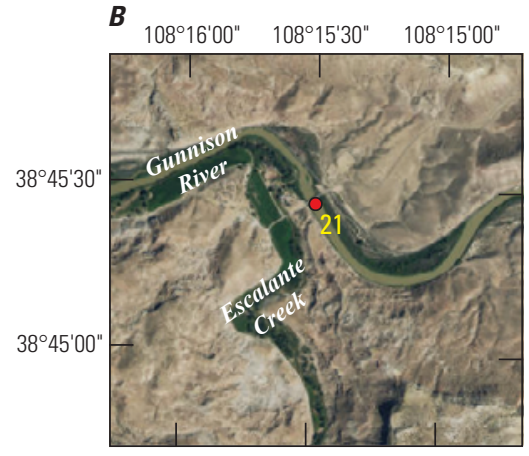

Base from U.S. Geological Survey digital data, 1:50,000 Universe Transverse Mercator projection, Zone 13 North American Datum of 1983 (NAD 83)

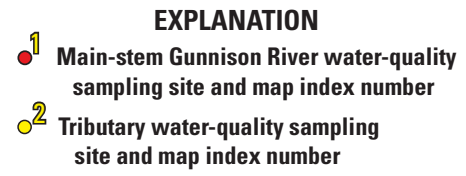

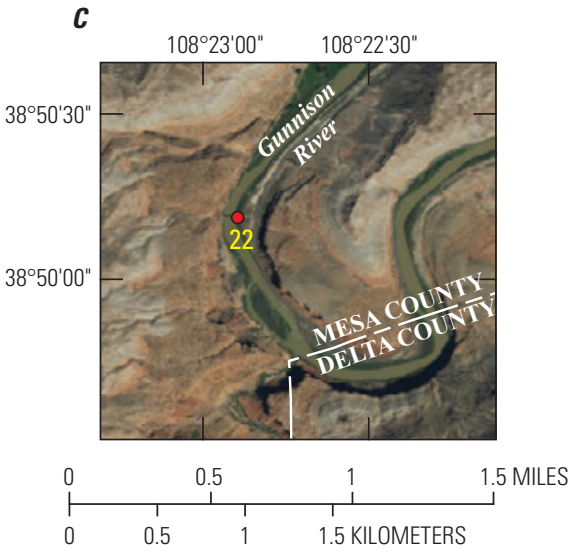

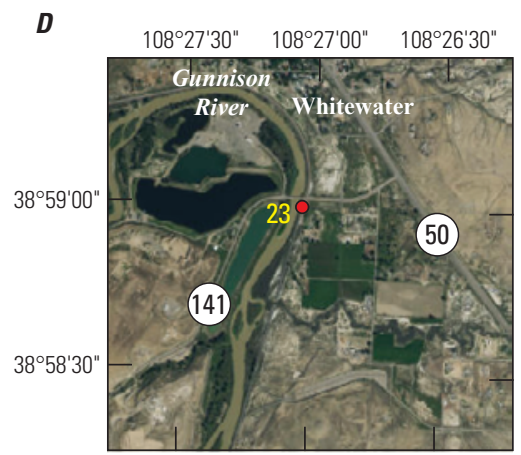

Map image is the intellectual property of ESRI and is used herein under license. Copyright (C) 2014 ESRI and its licensors. All rights reserved.

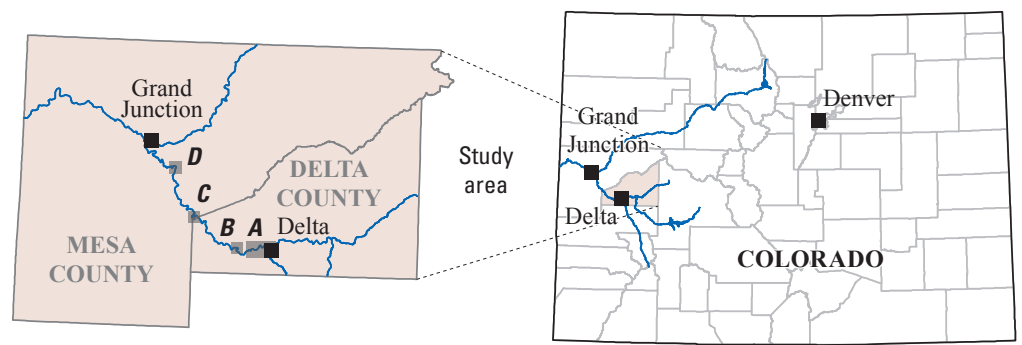

Figure 2. Location of the study reach and sites sampled during the synoptic study, Delta County, Colorado. $A$, sites within the synoptic reach and tributary sampling sites 1 through 20; $B$, location of site 21; $C$, location of site 22; and $D$, location of site 23; Sites 21,22 , and 23 are three additional main-stem sites at the lower end of the Gunnison River downstream from the synoptic reach. 
Junction (table 2, site 23) potentially could contribute up to almost 20 percent of the total Se load from the LGRB. This missing Se load was hypothesized to be caused by measurement error, Se loading from tributaries inputs, groundwater inflow, trends, and geochemical mobilization of Se to the system, or a combination of all these factors. Identification and quantification of Se sources in the study reach was needed by the SMP to help prioritize Se loading mitigation. In response to the need for more information about Se sources and transport, the USGS, in cooperation with the Colorado Water Conservation Board, completed a study that characterized Se loads in a reach of the Gunnison River between Delta and Grand Junction.

\section{Purpose and Scope}

The purpose of this report is to identify where possible dissolved Se loading is occurring in a study reach in the LGRB between Delta and Grand Junction, Colo. This report documents the methods and results of the synoptic sampling completed on this reach on November 19, 2015. In all, 20 samples were collected from known tributaries and the Gunnison River. These data were the basis for comparing the mass balance of measured inputs of streamflow and Se load from those tributaries to the streamflow and Se loads measured in the main-stem Gunnison River in the same reach. Three additional main-stem Gunnison River sites downstream from the synoptic reach also were sampled to provide supplementary information.

\section{Previous Investigations}

Selenium in the LGRB has been studied extensively in previous investigations. Butler and others (1996) described the occurrence of Se in parts of the Gunnison and Uncompahgre River Basins associated with surface water, groundwater, soils, sediments, and biota. Water resources have been developed primarily to facilitate irrigated agriculture. High levels of salt and Se were associated with irrigated land overlying marine shale-derived material (Butler and others, 1991; Butler and others, 1996; Evangelou and others, 1984; Leib and others, 2012; Tuttle and Grauch, 2009), a common land use and soil association in the LGRB. Excess water, not consumptively used by crops, removed by surface runoff, or evaporated, infiltrates to soil and rock, then percolates and migrates along shallow and deep pathways as part of the groundwater flow system. Seepage from canals, ditches, and ponds also contribute to deep percolated water (Butler, 2001). Lands developed for residential and recreational purposes contribute water to surface runoff and percolation from use of septic systems and application of water for landscaping purposes (Moore, 2011). Seleniumbearing minerals, contained in soils and weathered bedrock (Mast and others, 2014), are weathered under favorable geochemical or physical conditions, making the Se susceptible to transport as water migrates to streams by groundwater and surface-water pathways (Leib and others, 2012; Tuttle and others, 2014). Of Se loads at Colorado River at the Colorado-Utah stateline during the period 1997 to 2006, Leib (2008) reported that 52 percent of the load was derived from the Gunnison River Basin. Henneberg (2016) conducted a trend analysis for the Gunnison River near Grand Junction (09152500), which indicated a downward trend in Se load, decreasing 27.9 percent $(5,800 \mathrm{lb}$ per year) from WY 1992 to 2014. Also reported was that among five sites with continuous streamflow record and computed daily Se concentrations (from linear regression models) in the Gunnison Basin, at two sites, the Uncompahgre River at Delta and the Gunnison River near Grand Junction, the annual 85th percentile concentrations exceeded the State of Colorado water-quality standard for Se (dissolved) of 4.6 micrograms per liter $(\mu \mathrm{g} / \mathrm{L})$ (Henneberg, 2016).

\section{Methods}

During August 2015, a field reconnaissance was conducted with a boat on the Gunnison River to investigate potential surface-water loading sources along the study reach (fig. 2, table 1). The study reach was from the Gunnison River on downstream side of U.S. Highway 50 bridge at Delta (site 1) to the Gunnison River below Roubideau Creek (site 20) (fig. 2, table 1). During this reconnaissance, tributaries to the Gunnison River were identified and evaluated for accessibility along the study reach. Tributaries were identified as surface-water inputs to the Gunnison River that were visible from the boat. Field notes were collected that included estimates of streamflow and observations on color, turbidity, and potential sources. Sampling locations on the main stem of the Gunnison River were chosen based on information collected during the reconnaissance as well as on data-collection logistics such as ability to wade the cross section, tributary locations, and safety considerations. For the loading analysis, samples also were ultimately collected at three more sites on the Gunnison River (fig. 2, table 2): Gunnison River above Escalante Creek near Delta (site 21); Gunnison River below Dominguez Creek near Whitewater (site 22); and Gunnison River near Grand Junction (site 23). Data generated during this study are available at the USGS National Water Information System (NWIS) website (https://doi.org/10.5066/F7P55KJN).

The reconnaissance informed a synoptic sampling design for the Gunnison River reach, which required sampling of all known surface-water sources to the river during a short, stable period of streamflow. This allowed a determination to be made to test whether computed tributary input loads of dissolved Se could account for the changes in Se load in the Gunnison River during the same stable flow period. A day and season were chosen such that streamflows in the tributaries and the river were not changing and were as steady state as possible. These conditions reduce additional error and uncertainty because all measurements cannot be completed at the same time and travel times of inputs cannot be explained. The mass 
Table 1. Selenium concentration, streamflow, selenium load, and selenium load error for the synoptic samples collected November 19, 2015, near Delta Colorado.

[Cumulative distance is distance along the main-stem Gunnison River, in feet downstream from Highway 50 bridge at Delta; nr, near; $\mu \mathrm{g} / \mathrm{L}$, micrograms per liter; $\mathrm{ft}^{3} / \mathrm{s}$, cubic feet per second; $1 \mathrm{~b} / \mathrm{d}$, pounds per day; na, not applicable; <, less than; SWA, State Wildlife Area; Rd, road; Ln, lane]

\begin{tabular}{|c|c|c|c|c|c|c|c|}
\hline $\begin{array}{c}\text { Site } \\
\text { number } \\
\text { (fig. 2) }\end{array}$ & $\begin{array}{l}\text { U.S. Geological } \\
\text { Survey site } \\
\text { number }\end{array}$ & U.S. Geological Survey site name & $\begin{array}{l}\text { Cumulative } \\
\text { distance down- } \\
\text { stream (feet) }\end{array}$ & $\begin{array}{l}\text { Dissolved selenium } \\
\text { concentration } \\
\text { in loading } \\
\text { analysis }(\mu \mathrm{g} / \mathrm{L})\end{array}$ & $\begin{array}{c}\text { Streamflow } \\
\text { used in loading } \\
\text { analysis }\left(\mathrm{ft}^{3} / \mathrm{s}\right)\end{array}$ & $\begin{array}{c}\text { Computed } \\
\text { selenium load } \\
(\mathrm{Ib} / \mathrm{d})\end{array}$ & $\begin{array}{c}\text { Selenium } \\
\text { load error } \\
\text { (lb/d) }\end{array}$ \\
\hline 1 & 384502108041101 & Gunnison River on downstream side of Highway 50 bridge at Delta & 33 & ${ }^{1} 1.4$ & ${ }^{1} 1,510$ & ${ }^{1} 11.4$ & 1.6 \\
\hline 2 & 384502108042701 & Drainage ditch at confluence park at Delta & 1,870 & 18.9 & 1.67 & 0.086 & 0.034 \\
\hline 3 & 09144250 & Gunnison River at Delta & 2,887 & 1.5 & 1,510 & 12.2 & 2.0 \\
\hline 4 & 09149500 & Uncompahgre River at Delta & 7,119 & 11.2 & 321 & 19.4 & 2.0 \\
\hline na & calculation & Combined Gunnison River at Delta and Uncompahgre River at Delta & 7,119 & 23.2 & ${ }^{2} 1,831$ & ${ }^{2} 31.6$ & 3.7 \\
\hline 5 & 38451710855902 & Delta sewer, treated water & 11,483 & 6.3 & 1.47 & 0.049 & 0.010 \\
\hline 6 & 384457108055801 & Drainage ditch near 1400 Road at mouth & 11,942 & 9.5 & 2.5 & 0.128 & 0.026 \\
\hline 7 & 384520108060201 & Drainage ditch at Delta Sewer Plant bottomlands & 12,369 & 27.8 & 0.053 & 0.008 & 0.002 \\
\hline 8 & 384500108061901 & Unnamed drain at Townsend Road nr Delta & 13,058 & 5.7 & 0.006 & $<0.001$ & $<0.001$ \\
\hline 9 & 384545108061601 & West unnamed drain at Hwy 50, near Delta & 15,190 & 50.6 & 0.042 & 0.011 & 0.003 \\
\hline 10 & 384452108071101 & Gunnison River at G50 Road near Delta & 20,440 & 13.3 & ${ }^{1} 1,810$ & ${ }^{1} 32.0$ & 2.0 \\
\hline 11 & 384448108070301 & Cummings Gulch at mouth & 21,325 & 6.8 & 7.83 & 0.287 & 0.024 \\
\hline 12 & 384438108072301 & Unnamed drain downstream of G50 Road nr Delta & 22,310 & 6.3 & 0.56 & 0.019 & 0.004 \\
\hline 13 & 384432108074001 & Unnamed drain at Sawmill Mesa Rd and G Ln nr Delta & 23,786 & 9.2 & 0.35 & 0.017 & 0.003 \\
\hline 14 & 384454108080101 & Lateral Tailwater at G50 Road, near Escalante SWA & 25,722 & 6.7 & 0.02 & 0.001 & $<0.001$ \\
\hline 15 & 384435108091801 & East unnamed drain at Escalante SWA nr Delta & 32,218 & 59.1 & 0.005 & 0.002 & $<0.001$ \\
\hline 16 & 384439108092801 & Central unnamed drain Escalante SWA nr Delta & 33,038 & 69.5 & 0.021 & 0.008 & 0.002 \\
\hline 17 & 384439108093201 & West unnamed drain at Escalante SWA nr Delta & 33,399 & 284 & 0.099 & 0.152 & 0.046 \\
\hline 18 & 384408108091501 & Seep Creek at G Road near mouth & 37,434 & 4.3 & 5.10 & 0.118 & 0.024 \\
\hline 19 & 09150500 & Roubideau Creek at mouth near Delta & 38,058 & 2.0 & 37.8 & 0.408 & 0.052 \\
\hline 20 & 384401108100501 & Gunnison River below Roubideau Creek near Delta & 39,895 & 13.4 & ${ }^{1} 1,850$ & 133.4 & 2.0 \\
\hline
\end{tabular}

${ }^{1}$ Mean concentration, streamflow, and load are given because multiple measurements and samples were collected.

${ }^{2}$ Streamflow and loads are the sum of site 3 and site 4 , concentration is sum of loads of site 3 and site 4 divided by streamflow, and then divide the result by 0.0054 (unit conversion constant to get $\mu \mathrm{g} / \mathrm{L}$ ).

Table 2. Selenium concentration, streamflow, selenium load, and selenium load error at additional sites downstream from the synoptic reach, near Delta, Colorado (tributary inflows were not determined between site 20 [table 1] and site 23).

[Cumulative distance is distance along the main-stem Gunnison River, in feet downstream from Highway 50 bridge at Delta; ab, above; blw, below; $\mu \mathrm{g} / \mathrm{L}, \mathrm{micrograms}$ per liter; ft³/s, cubic feet per second; lb/d, pounds per day]

\begin{tabular}{|c|c|c|c|c|c|c|c|}
\hline $\begin{array}{c}\text { Site } \\
\text { number } \\
\text { (fig. 2) }\end{array}$ & $\begin{array}{c}\text { U.S. Geological } \\
\text { Survey station } \\
\text { number }\end{array}$ & U.S. Geological Survey station name & $\begin{array}{l}\text { Cumulative } \\
\text { distance down- } \\
\text { stream (feet) }\end{array}$ & $\begin{array}{l}\text { Selenium concen- } \\
\text { tration in loading } \\
\text { analysis ( } \mu \mathrm{g} / \mathrm{L})\end{array}$ & $\begin{array}{c}\text { Streamflow } \\
\text { used in loading } \\
\text { analysis }\left(\mathrm{ft}^{3} / \mathbf{s}\right)\end{array}$ & $\begin{array}{c}\text { Computed } \\
\text { selenium load } \\
(\mathrm{lb} / \mathrm{d})\end{array}$ & $\begin{array}{l}\text { Selenium } \\
\text { load error } \\
\text { (lb/d) }\end{array}$ \\
\hline 21 & 384527108152701 & Gunnison River ab Escalante Creek, near Delta & 52,493 & 3.4 & 1,830 & 33.7 & 3.9 \\
\hline 22 & 385011108225401 & Gunnison River blw Dominguez Creek near Whitewater & 68,898 & 3.5 & 1,880 & 35.6 & 7.7 \\
\hline 23 & 09152500 & Gunnison River near Grand Junction & 82,021 & 3.7 & 1,820 & 36.5 & 4.6 \\
\hline
\end{tabular}


balance of these tributary loads were then compared to loads in the main-stem synoptic reach such that locations of diffuse groundwater inputs can be identified by a change in load not related to a tributary source. The synoptic sampling for this study was conducted on a single day, November 19, 2015, during a period when streamflows were low, minimal changes in streamflow occurred, and there were no snowmelt, evapotranspiration, or ice melt diurnal variations. These conditions made it more likely that groundwater inputs to the river would be noticeable in a mass balance.

\section{Streamflow Measurement Methods}

Streamflow information is important in the computation of Se loads, assessment of gain or loss of water within the stream reach, and assessment of the stability of flow rates to verify the assumption of steady-state conditions necessary for accumulating streamflow and loads from upstream to downstream. In this section, methods for two types of measurements used in this study are described: (1) streamflow from streamflow gages, and (2) discrete measurements of streamflow.

\section{Streamflow Gages}

Streamflow gages provide continuous record of stage that is converted to streamflow using a rating curve that relates the stage at the gage to a measured streamflow from an instantaneous streamflow measurement in the vicinity of the gage. The result of computations or measurements of streamflow also are known as streamflow discharge (or discharge). Available records at three streamflow gages were used to compute a mass balance of streamflow. The Gunnison River at Delta streamflow gage (site 3 ) is located at the upstream end of the study reach, the Uncompahgre River at Delta site (site 4) is located on the largest tributary in the study reach, and the Gunnison River near Grand Junction site (site 23) is located about 14 miles downstream from the confluence of the Gunnison and Uncompahgre Rivers at the end of the reach used for this study. Differences between the combined flows of the Gunnison and Uncompahgre Rivers in Delta with the Gunnison River near Grand Junction provided a means to begin to assess the contributions of ungaged tributaries, surface-water diversions, and groundwater gains and losses between Delta and Gunnison River near Grand Junction.

The streamflow data were combined without any temporal shifts that would account for the travel times of water between sites. Instead, extending the averaging time from one day to a larger number of days was used to compensate for the travel times, as well as to account for attenuation of streamflow during periods of changing flow (diurnal fluctuations and rain and snowmelt runoff peaks) that daily mean comparisons would not explain. Daily mean flows at the 3 sites (calculated from 15-minute unit values) for 5 WYs 2011-2015 were transformed to a 5-day moving average (Zivot and Wang, 2006) for each day (Additional water-quality and streamflow data are available from the USGS NWIS website at https:// doi.org/10.5066/F7P55KJN). The moving average transformed daily mean streamflows at sites 3 and 4 were subtracted from those at site 23 , resulting in a difference expressed as daily value in cubic feet per second $\left(\mathrm{ft}^{3} / \mathrm{s}\right)$.

\section{Discrete Measurement of Streamflow}

Five sites on the Gunnison River with no streamflow gages also were sampled during the synoptic study. From upstream to downstream these sites were sampled (fig. 2, tables 1 and 2): Gunnison River on downstream side of U.S. Highway 50 bridge at Delta (384502108041101, site 1); Gunnison River at G50 Road near Delta (384452108071101, site 10); Gunnison River below Roubideau Creek near Delta (384401108100501, site 20); Gunnison River above Escalante Creek near Delta, (384527108152701, site 21); and Gunnison River below Dominguez Creek near Whitewater (385011108225401, site 22). As a result of high streamflow volume and velocity, the Gunnison River was not wadable during the synoptic study. Boat measurements were taken using an Acoustic Doppler Current Profiler (ADCP's) at mainstem Gunnison River sites. At each of the main-stem sites, two staff members made the ADCP streamflow measurements following standard methods (Mueller and others, 2013).

Streamflow was measured at tributary sites on the north and south sides of the Gunnison River on the day of the synoptic sampling between Gunnison River on downstream side of U.S. Highway 50 bridge at Delta (site 1) down to Gunnison River below Roubideau Creek near Delta (site 20), where measureable flow was present (table 1). Three other Gunnison River sites on the Gunnison River downstream from site 20 (sites 21, 22, and 23) also were sampled for Se for additional perspective in the reach downstream on the Gunnison River to site 23, which was noted in the literature (in the "Introduction" section of this report) that prompted this investigation. Wading measurements using the midsection method (Turnipseed and

Sauer, 2010) were performed using current meters for wadable sites. Measurements were made using a Sontek Flowtracker Acoustic Doppler Velocimeter or pygmy current meters (Turnipseed and Sauer, 2010). Some tributary sites were too shallow or narrow for standard current-meter measurements, so flows were estimated. The estimates were done by using a current meter to measure any velocities that could be obtained. These depths were not always at 60 percent of the depth as measured from the water surface, as is standard measurement procedure, but were still used to estimate streamflow. The mean of those velocities was then multiplied by the crosssectional area obtained with a wading rod and cross-sectional width increments as conditions allowed. 


\section{Water-Quality Measurements and Sampling on Main-Stem and Tributary Sites}

Water-quality samples were collected using procedures described by the "National Field Manual for the Collection of Water-Quality Data," (USGS, variously dated), and associated with a field streamflow measurement at the site or a streamflow value from a continuous streamflow gage. The Gunnison River was not wadable during the day of the synoptic sampling, and water-quality samples were collected from boats at sites on the main stem using an extended depthintegrated handheld (DH) -81 sampler, which is an extension rod that is attached to the standard rod used with a DH-81 sampler during wading measurements. This rod extension allowed the hydrographer to lower the DH-81 through the water column from a sitting position in the boat if water was shallow. When water was too deep to deploy a DH-81 sampler, a D-95 sampler, which is a larger and heavier cablesuspended sampling device, was lowered through the water column using a crane apparatus mounted on the boat. The hydrographer turns a crank, which raises and lowers the sampler. A calibrated depth readout gage allows the hydrographer to identify the depth at which the sampler is located. These samples were collected isokinetically using equal-width increment methods to obtain representative samples and using USGS sampling procedures to avoid contamination (USGS, variously dated). Aliquots from the sampler (representing various sections of the sampling transect) were composited in a polyethylene churn splitter. Streamflow data were collected at these three main-stem sites (sites 3, 4, and 20) four times during the day of the synoptic sampling at roughly 1- to 2-hr intervals, using an ADCP. These multiple measurements were used to verify that streamflow was not changing during the sampling at sites where no continuous streamflow gage was installed. Field properties, including $\mathrm{pH}$, temperature, specific conductance, and dissolved oxygen, were measured with each discrete water-quality sample collected for laboratory analysis (USGS, variously dated). These data enabled a further assessment of water-quality stability.

At tributary sites, water-quality samples were collected using equa-width increment method and DH-81 sampler if field conditions permitted (USGS, variously dated). When velocity was below the minimum threshold for isokinetic sampling or depths were too shallow, grab samples were collected with an open-mouth bottle at multi-vertical or single vertical locations within the cross section.

All samples were processed in a mobile water-quality laboratory at a centralized location following standard methods (USGS, variously dated). During processing, raw sample water was mixed in the churn splitter prior to filtering and filling sample bottles. Water samples collected for the analysis of alkalinity (field analyzed), major inorganic constituents (cations and anions), dissolved solids, nutrients, dissolved organic carbon, and trace elements (including dissolved Se) were filtered in the field by using a 0.45 -micron capsule filter preconditioned with deionized water and placed in prerinsed bottles (except for dissolved organic carbon). Selenium was the primary focus of this study; the other constituents collected were for the purposes of "fingerprinting" any sources of groundwater that may have been indicated by the mass balance of streamflows or Se. These other constituents will not be discussed further in this report except in this section and in the ion balance discussion in the "Quality Assurance" section of this report. Alkalinity was determined in the field by incremental titration. Samples for cation and dissolved Se analyses were acidified to a $\mathrm{pH}$ of less than 2 by the addition of 2 milliliters of 7.5 normal, Ultrex nitric acid. Samples for dissolved organic carbon analysis were acidified to a pH of less than 2 with 1 milliliter of 4.5 normal sulfuric acid. Field properties and sampling information were entered into Personal Computer Field Form (USGS, variously dated) and then uploaded into the data storage and management component of NWIS. Samples were analyzed by the USGS National Water Quality Laboratory in Lakewood, Colo. Laboratory analyses of major ions, nutrients, and dissolved organic carbon were done using standard procedures for major ions and trace elements (including Se) (Fishman, 1993; Fishman and Friedman, 1989; Garbarino, 1999; Garbarino and others, 2006). Nutrient methods are described by Fishman (1993); Patton and Kryskalla (2003); Patton and Kryskalla (2011). Organic carbon methods are described in Brenton and Arnett (1993).

\section{Quality Assurance}

Overall data quality for each sample was assessed by calculation of charge (milliequivalent) balance. A charge imbalance of less than or equal to 5 percent is considered desirable. Milliequivalent balances for major ions (cations and anions) were calculated according to methods described by Hem (1985). Typically, the major ions are the principal contributors of electrical charge for dissolved constituents in water, and their sum should be close to zero. Departures from zero may indicate inaccurate major-ion analyses but do not assess minor constituents (including dissolved Se). In this study, 73 percent of environmental samples (nonquality assurance samples) had charge balances of less than 5 percent overall (median of 1.3 percent), indicating generally good major-ion analytical results and no major indications of problems.

Quality assurance in this study was determined using results from four replicate split samples and two blanks (USGS, variously dated). These field samples, in addition to laboratory analytical rerun requests, were approximately 19 percent of the samples collected. Quality-assurance samples were collected for major ions, nutrients, dissolved organic carbon, and dissolved Se. All water-quality tasks followed USGS procedures (USGS, variously dated)

Selenium concentrations in the two field blanks were both less than the detection level for dissolved Se $(<0.05 \mu \mathrm{g} / \mathrm{L})$ and indicated no substantial contamination during collection and processing of samples. The relative percentage difference (RPD) for the environmental and replicate or environmental 
and rerun sample values was calculated according to the following equation as described in Bossong and others (2006):

$$
\mathrm{RPD}=\{(a-b) /[(a+b) / 2]\} \times 100,
$$

where:

$$
\begin{aligned}
& a \quad \text { is the constituent concentration in the } \\
& \text { environmental or primary analysis sample; } \\
& \text { and } \\
& b \quad \text { is the constituent concentration in the } \\
& \text { replicate or secondary analysis sample. }
\end{aligned}
$$

The replicate and rerun data indicated generally reproducible analytical results for dissolved Se. The RPDs for the two split replicates were about 2.7 and 7.9 percent. Laboratory reruns of analyses for Se help define the precision of laboratory results. Of the 30 Se rerun result pairs, the median percentage difference was 4.4 percent and ranged from 0.2 to 16.9 percent. A high RPD indicates higher variability and uncertainty of analytical results. Large uncertainty can decrease the reliability and increase the error of loads in a synoptic mass balance.

\section{Load Computations}

Concentration of dissolved Se is shown in this report in micrograms per liter $(\mu \mathrm{g} / \mathrm{L})$, and load is reported as pounds per day $(\mathrm{lb} / \mathrm{d})$. The load or mass of Se transported in streams over a period helps with the interpretation of potential effects of inflows on downstream receiving streams. In this study, loads of Se were used to create a mass balance of Se inputs compared to downstream loads in the Gunnison River.

Load values are used to determine the relative amounts of each constituent contributed by different source areas. Load is calculated by using the following equation (Leib, 2008):

$$
L=C \times Q \times K,
$$

where:

$$
\begin{aligned}
& L \quad \text { is constituent load, in pounds per day; } \\
& C \text { is constituent concentration, in micrograms } \\
& \text { per liter for selenium; } \\
& Q \quad \text { is streamflow, in cubic feet per second; and } \\
& K \quad \text { is the unit conversion constant, } 0.0054 \text { to } \\
& \text { calculate pounds per day units. }
\end{aligned}
$$

\section{Error Analysis}

As Se loading is the subject of this report, an error analysis focused on the two variable components of load calculations: (1) streamflow discharge, and (2) concentration of Se. The results of the discharge and concentration error computations were then propagated into the loading error computations. An assessment of error is important for interpretation of synoptic results because uncertainty in streamflow measurements and water-quality analytical methods may be larger than the differences in load observed in the analysis.
The following method of error propagation relies on a method described in Bevington and Robinson (2003) and was applied to water-quality loading analysis developed in Williams and Leib (2005) and Leib (2008).

Four methods were used to determine streamflow discharge in the synoptic study: (1) discharge from records at streamflow gages, (2) discharge measured with a current meter, (3) discharge measured with ADCPs, and (4) estimated discharges. Discharge errors associated with these measured discharges were (1) for instantaneous discharge from streamflow gage records, error was the percentage value of the rating of the published daily discharge record during that period; (2) for measured discharges by current meter, error was based on qualitative rating by the hydrographer for the measurement; (3) for main-stem sites with multiple ADCP measurements error was the standard deviation (SD) of all daily transect pairs during steady-state conditions; and (4) estimated discharges were rated very poor (30 percent error for this report).

Discharges obtained from streamflow record at a streamflow gage were assigned errors using the rating (and expression of the quality of the data and computations such as "good" or "poor" assigned by the hydrographer who worked the record) of the daily discharge record on the day of the synoptic sampling in the 2016 WY "water summary" on NWIS web (https://doi.org/10.5066/F7P55KJN). The "WRD Data Reports Preparation Guide," U.S. Geological Survey Open-File Report 85-480) by Novak (1985) was then consulted to determine potential error (accuracy). "Four accuracy classifications are used to rate station records. A rating 'excellent' means that about 95 percent of the daily discharges are within 5 percent of the true discharge; 'good' within 10 percent; 'fair' within 15 percent; and 'poor' means that daily discharges have less than 'fair' accuracy. An accuracy rating is assigned only after the daily discharge computations are complete. All records should be computed with equal care and to the greatest degree of accuracy possible under existing conditions" (Novak, 1985, p. 65). These ratings are based on the reliability of the computations considering site conditions and quality of measurements used to construct the stage-discharge relation.

Another rating system for instantaneous measurements exists, whether done with a mechanical current meter (pygmy meter), ADCP, or an Acoustic Doppler Velocimeter (Sontek Flowtracker), and ratings were based on equipment performance, site conditions, and the adherence to good practice of the streamflow measurement methods. Performance of the meter is important such as the diagnostics of an Acoustic Doppler Velocimeter, or the spin test time for a mechanical current meter. Site conditions that are important include stability of the substrate (bed material) and bank material, whether an accurate depth can be determined (boulders make representative depths of a particular vertical difficult, or run up [of the water surface] on the wading rod or suspension cable also adds uncertainty), whether banks are undercut (making access to the full width impossible), inconsistency of the flow velocity or turbulence (adds uncertainty to velocity observations), and the presence of floating debris or bank vegetation interfering with 
the current meter. The streamflow measurement also should be performed in such a way that no more than the desired rating percent of discharge should be contained in any one section (discharge represented by any single vertical). For example, if a measurement rating of "good" is the goal (depending on site conditions), no single vertical should exceed 5 percent of the total discharge. The hydrographer assesses the result of all of these effects on potential error after making the measurement. Next, the observations are recorded and a rating for the measurement is assigned: excellent, 2 percent; good, 5 percent; fair, 8 percent; poor, greater than 8 percent (Turnipseed and Sauer, 2010) (20 percent was used in this report for a poor measurement rating). If no measurement rating was available from the hydrographer, the measurement was rated by the author for the analysis based on available information. Estimated discharges, described earlier as measurements that were nonstandard because of depth, width, or velocity limitations, were rated very poor (30 percent) for this report.

Another method was used for computing error for ADCP streamflow measurements where multiple determinations were made, for main-stem Gunnison River samples at sites 1,10 , and 20 under steady-state conditions. Each streamflow measurement consists of multiple reciprocal-traverse, transect pairs. USGS guidance for a streamflow measurement requires a total of at least 12 minutes of acoustic data collection, completed in reciprocal-traverse, transect pairs; for this study, each measurement comprised 4 to 6 of these pairs. The SD of all daily transect pairs at each of the three ADCP measurement sites was an indicator of precision used in the streamflow and load error analysis.

Analytical error or uncertainty of Se concentrations was assessed for this report by determining the precision of a concentration result using replicate samples (two samples drawn from the same composited raw sample and analyzed by the same laboratory procedure) and laboratory rerun results. Two replicate pairs and 32 rerun analyses were collected during the synoptic sampling, and the differences were described previously in the "Quality Assurance" section. The SD of the absolute value of differences between the environmental samples and either the Se replicates or the laboratory rerun concentrations were used as an indicator of precision for this error analysis. Absolute differences in units of micrograms per liter tend to be larger at larger concentrations; whereas, they tend to be smaller for smaller concentrations. To limit the effect of using a single SD (in micrograms per liter) and the resulting bias, small concentrations would have the same absolute error as large concentrations; therefore, the concentrations were divided into two groups before determining averages: samples with concentrations less than $12 \mu \mathrm{g} / \mathrm{L}$ (27 samples, range from 1.4 to $12 \mu \mathrm{g} / \mathrm{L}$, average SD was $0.2 \mu \mathrm{g} / \mathrm{L}$ ), and samples greater than $12 \mu \mathrm{g} / \mathrm{L}$ ( 5 samples, range from 27 to $272 \mu \mathrm{g} / \mathrm{L}$, average SD was $6.1 \mu \mathrm{g} / \mathrm{L}$ ). Analytical error for samples in each group was then assigned the average SD for that group.

The streamflow and analytical error is then propagated as a compounded error for the load computations using an equation from Bevington and Robinson (2003) and described in Williams and Leib, (2005) and (Leib, 2008):

$$
\sigma_{L}=\left(\sqrt{\left(\frac{\sigma_{Q}}{Q}\right)^{2}+\left(\frac{\sigma_{C}}{C}\right)^{2}}\right) \times L,
$$

where:

$\sigma_{L}$ is the compounded error for constituent load, in pounds per day;

$\sigma_{Q} \quad$ is the error of the streamflow measurement, in cubic feet per second;

$Q \quad$ is the measured streamflow, in cubic feet per second;

$\sigma_{C} \quad$ is the error of the concentration value, in micrograms per liter;

$C$ is the measured constituent concentration, in micrograms per liter; and

$L \quad$ is the measured load, in pounds per day.

These error estimates provide the measure of whether differences between cumulative loads from the tributaries and loads in the Gunnison River are greater than the range of error. If the differences are within the error range, it is less likely that evidence exists of a true difference.

\section{Streamflow and Selenium Loads}

The following sections describe the results of the synoptic sampling. The streamflow-gage analysis shows a comparison between upstream and downstream streamflow gages on the main-stem Gunnison River, which were used as an indicator of potential gains in the synoptic reach (from site 1 to site 20). A synoptic streamflow analysis (instantaneous measurements) at five locations provided the basis for determining gains or losses on the main-stem synoptic reach from Gunnison River on downstream side of U.S. Highway 50 bridge at Delta (site 1) down to Gunnison River below Roubideau Creek near Delta (site 20). An analysis of synoptic Se concentration and load for the main stem compared to concentrations and loads in tributaries was used to determine if diffuse sources of Se are entering the Gunnison River in the study reach. Three other Gunnison River sites downstream from site 20 also were sampled and may indicate further gains or losses, but tributaries in the reach below site 20 were not located or sampled during the study, so attributing gains or losses, such as quantifying diffuse gains from groundwater, was not possible.

\section{Streamflow-Gage Analysis}

Prior to the synoptic study, general gain-loss characteristics were evaluated in the reach of the Gunnison River where the synoptic survey would be conducted. The procedure described in the "Methods" section of this report combined 
the streamflows of sites 3 (09144250) and 4 (09149500) in Delta and subtracted them from the streamflow at site 23 (09152500), the Gunnison River near Grand Junction (fig. 1, tables 1 and 2). These daily differences, transformed into 5-day moving averages of the differences for the 2011 to 2015 WY period, were organized into 12 groups representing each month of the year (all available 5-year differences aggregated for the monthly statistics shown in each boxplot) (fig. 3). Note that not all days had daily values for all 3 sites as a result of missing data, which precluded a calculation of some differences during the 5-year period, as reflected in the "number of values" in figure 3. Each of the 12-month categories shows the distribution of the streamflow differences for that month, which can be interpreted as a gain or loss at downstream site 23 depending on the positive (gain) and negative (loss) values. Larger magnitudes represent larger gains or losses.

The streamflow difference analysis was useful, in conjunction with other lines of evidence, in interpreting the potential for groundwater gains or losses in the synoptic reach. Water surplus at the downstream site (from the analysis) can indicate that inflow sources exist and contribute to net increases in streamflow between the sites. Water deficit at the downstream site (from the analysis) can indicate potential losses from the stream to groundwater aquifers, consumptive losses (evapotranspiration), or withdrawals from surface-water diversions that might contribute to net decreases in streamflow between the sites.

The positive differences between the 5-day moving averages of daily streamflow during base flow (defined for

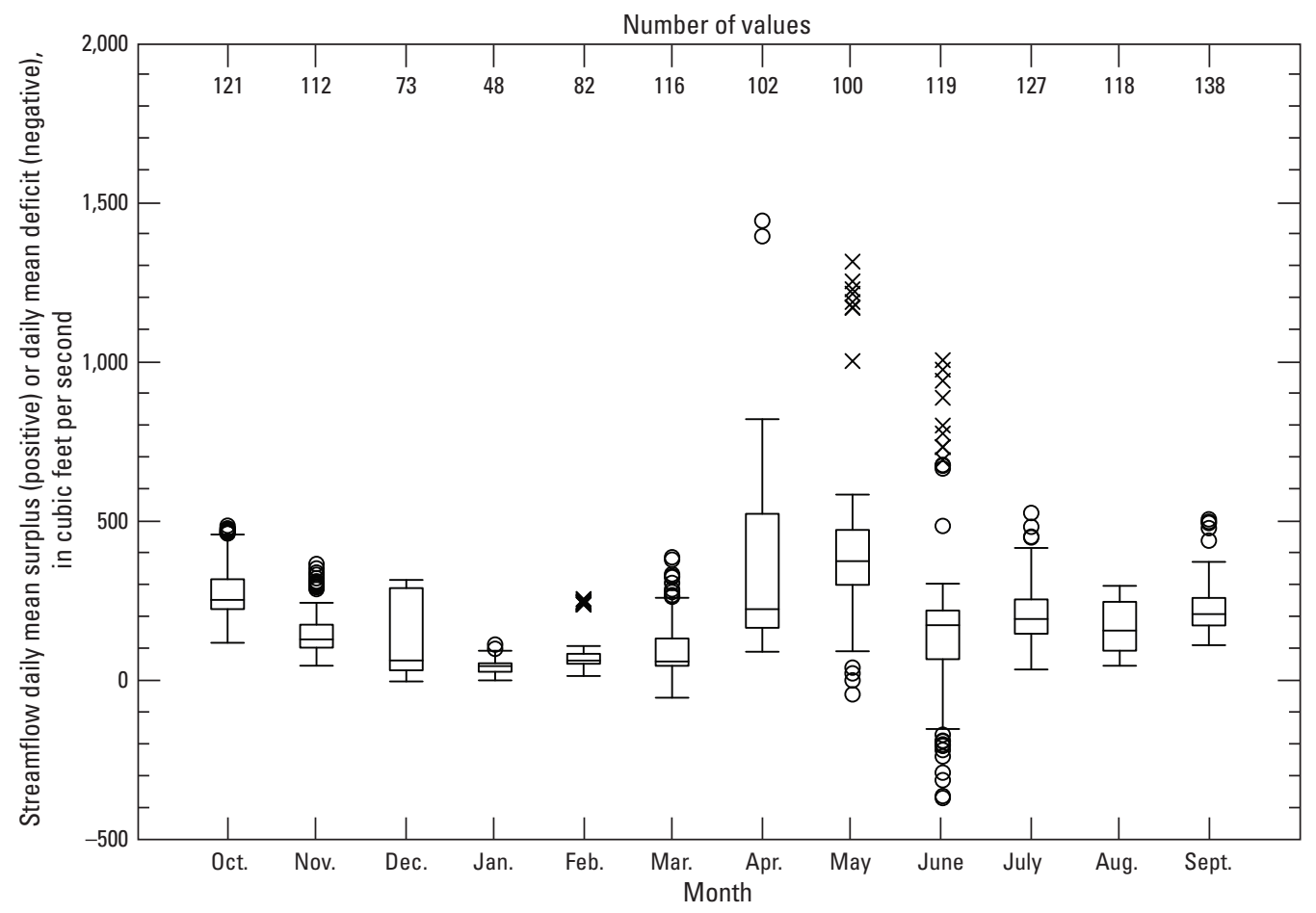

EXPLANATION

138 Number of values

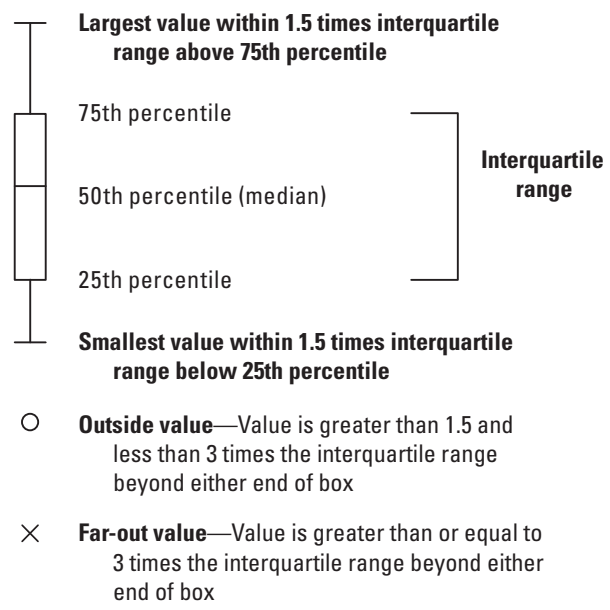

Figure 3. Streamflow gage record comparison of the average 5-day difference in combined streamflows of 09144250 (site 3) and 09149500 (site 4), and the downstream station 09152500 (site 23) for the 2011 through 2015 water years. Positive values of streamflow mean water surplus (gain between stations), and negative values mean water deficit (loss between stations). 
this analysis as November through March and also defined as nonirrigation season) were mostly smaller than other months of the year (April to October and also defined as irrigation season) (fig. 3). Nonirrigation season differences ranged from about -54.3 (March) to $388 \mathrm{ft}^{3} / \mathrm{s}$ (March) with median monthly differences ranging from 45.1 to $129 \mathrm{ft}^{3} / \mathrm{s}$. Positive differences during the nonirrigation season may indicate some contributing tributary base flows or diffuse inflows from groundwater between the upstream and downstream ends of the reach. The largest differences are in the irrigation season from April to June, likely a result of tributary inputs and irrigation return flows, and ranged from about $-369 \mathrm{ft}^{3} / \mathrm{s}$ (June) to $1,445 \mathrm{ft}^{3} / \mathrm{s}$ (April) with median monthly differences ranging from about 174 to $375 \mathrm{ft}^{3} / \mathrm{s}$. The apparent loss of some water during some periods in the months of May and June are not explained, and the base flow months do not show losses or losing reach characteristics. The few days of apparent losses in May-June (fig. 3) may be a result of diversions in the reach between the two sites, although none were identified in November 2015 for this study. Also, larger streamflows during the May-June runoff period may have larger absolute errors, and when expressed in terms of cubic feet per second, this uncertainty in the methods could result in negative differences in the streamflow computations during those periods. For example, a 5-percent error at 1,000 $\mathrm{ft}^{3} / \mathrm{s}$ (low flow) is $50 \mathrm{ft}^{3} / \mathrm{s}$. A 5-percent error at 7,000 $\mathrm{ft}^{3} / \mathrm{s}$ (high flow) is $350 \mathrm{ft}^{3} / \mathrm{s}$. If the error is high at the upstream sites and low at the downstream site, it could contribute to the negative differences observed in figure 3. Positive differences between the combined flows of the Gunnison and Uncompahgre Rivers in Delta (sites 3 and 4) with the Gunnison River near Grand Junction (site 23) added evidence to a preliminary hypothesis that contributions of ungaged tributaries or gains from diffuse groundwater inflow between Delta and Gunnison River near Grand Junction (or both) may be occurring during base flow (nonirrigation) periods.

\section{Results of Synoptic Streamflow Analysis}

In this report, there are two reaches of interest: the synoptic reach with tributary sampling (sites 1 through 20), and three additional main-stem sites at the lower end of the Gunnison River (sites 21 through 23), which are outside the fully characterized synoptic reach. The synoptic reach had main-stem and tributary streamflow measurements, which allow for computation of diffuse groundwater inflow. The extra main-stem sites could indicate if there is a gain or loss of streamflow, but with no tributary measurements from site 20 to site 23, any sources of gains or losses could not be specified.

Streamflow in the Gunnison River at site 1 (downstream side of U.S. Highway 50 bridge at Delta and upper end of the synoptic reach), the most upstream main-stem site, was about 82 percent $\left(1,510 \mathrm{ft}^{3} / \mathrm{s}\right)$ of the streamflow at the furthest downstream sample location at site $20\left(1,850 \mathrm{ft}^{3} / \mathrm{s}\right)$ (table 1 , fig. 2 , and fig. 4). After incorporating streamflows from the Uncompahgre River, $321 \mathrm{ft}^{3} / \mathrm{s}$ ( site 4 ), the streamflow in the main stem downstream from the confluence was essentially the same as

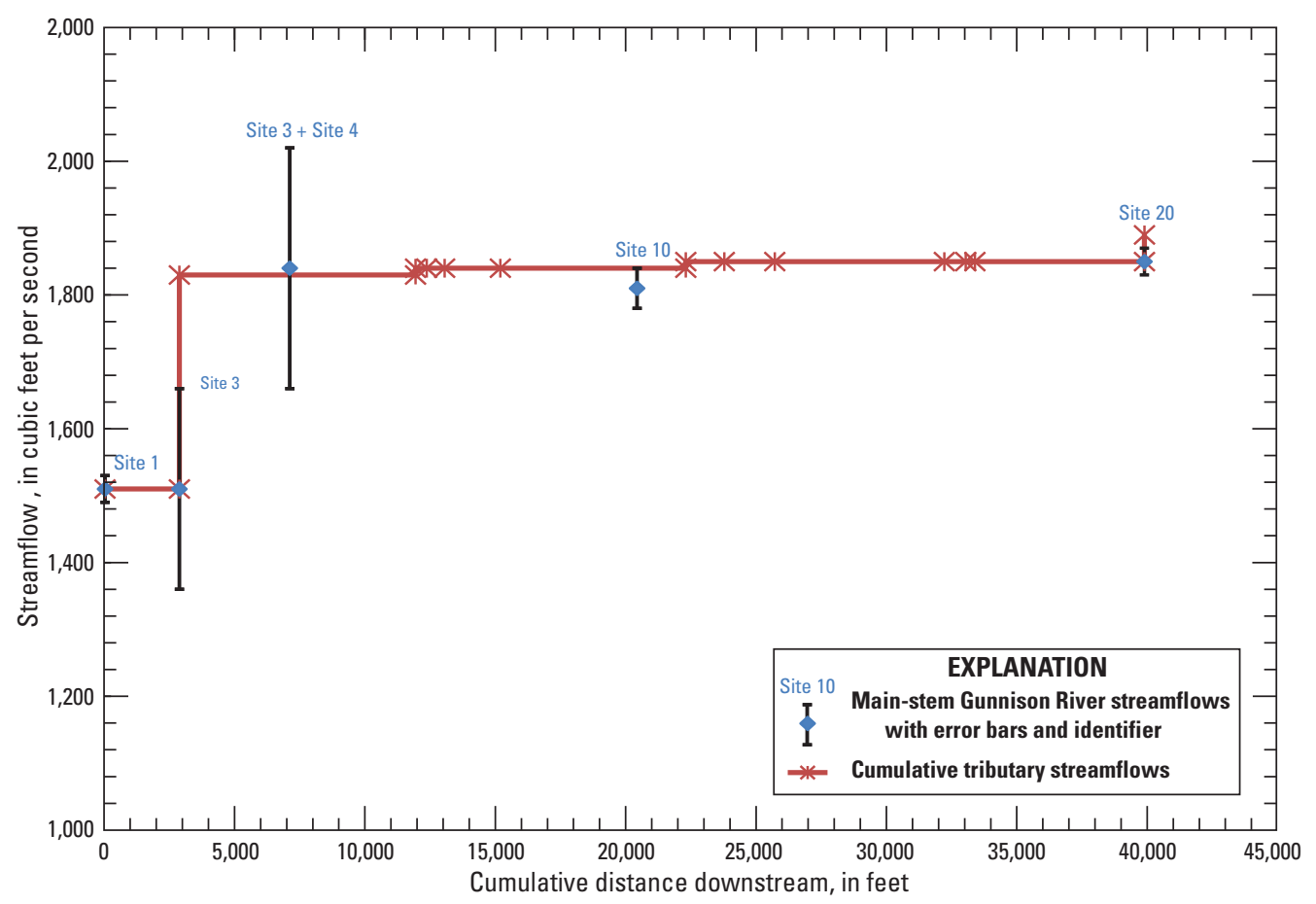

Figure 4. Main-stem Gunnison River streamflows along cumulative distance along the main-stem Gunnison River (in feet downstream from U.S. Highway 50 bridge at Delta, Colo.) with error bars corresponding to accuracy of the streamflow values, and cumulative measured tributary inflows to the main-stem Gunnison River. 
the furthest downstream site, site $20\left(1,831\right.$ and $1,850 \mathrm{ft}^{3} / \mathrm{s}$, respectively). All other tributary inflows were minor, proportionately. All inputs to the Gunnison River ranged between 0.005 (site 15) and $321 \mathrm{ft}^{3} / \mathrm{s}$ (site 4) (table 1), but 44 percent of the water inputs were less than or equal to $0.1 \mathrm{ft}^{3} / \mathrm{s}$. These low values were measured in 12 drains and ditches tributary to the Gunnison River, which ranged from $0.005 \mathrm{ft}^{3} / \mathrm{s}$ at site 15 to $2.5 \mathrm{ft}^{3} / \mathrm{s}$ at site 6 (table 1). The maximum tributary value of $321 \mathrm{ft}^{3} / \mathrm{s}$ was measured in the Uncompahgre River (site 4), the primary tributary to the Gunnison River in the study area. The main secondary tributary, based on streamflow, was Roubideau Creek (site 19) at $37.8 \mathrm{ft}^{3} / \mathrm{s}$. The remaining two tributaries had streamflow that ranged from 5.10 and $7.83 \mathrm{ft}^{3} / \mathrm{s}$ at sites 18 and 11, respectively. The three main-stem sites downstream from site 20 also showed no substantial changes in streamflow downstream from the synoptic reach (table 2), indicating no convincing evidence that net tributary or diffuse groundwater inflows are occurring at the main-stem sites.

Main-stem streamflows increased from upstream (site 1) to downstream (site 20). Of the three streamflow gages, (1) Gunnison River at Delta (09144250, site 3),

(2) Uncompahgre River at Delta (09149500, site 4), and

(3) Gunnison River near Grand Junction (09152500, site 23), the two in the synoptic reach (sites 3 and 4) were rated good for daily values of streamflow based on final records for the 2016 WY. Site 23, an extra site downstream from the synoptic reach, also was rated good. Novak, (1985) indicates that a record rated as "good" is defined as "... about 95 percent of daily discharges are within 10 percent of the true discharge" (Novak, 1985, p. 65). Thus, potential error from streamflow values was considered to be plus or minus 10 percent.

An additional downstream main-stem site, Gunnison River below Dominguez Creek near Whitewater (site 22) was rated poor and assigned an accuracy of "greater than 8 percent." Because the "poor" rating does not have a particular associated value, an accuracy of "within 20 percent" was used. Tributary inflow ratings ranged from fair (within 8 percent) to poor (greater than 8 percent, accuracy assigned at 20 percent). Four estimated measurements were also rated as poor, and an accuracy of "within 30 percent" was assigned because of the necessary use of particularly inaccurate methodology.

The lack of substantial increasing or decreasing main-stem streamflows in a downstream direction was not supportive of net inputs or outputs in the water balance. Some small gains and losses along the synoptic reach (inflows and seepage balancing evapotranspiration losses) may have been present, but no substantial net changes were recognizable. The cumulative tributary inflow (fig. 4) generally corroborates the evidence against the hypothesis of diffuse groundwater inflows (on this day), by showing that cumulative measured tributaries account for the main-stem streamflows mostly within the plotted error of the measurements. However, the cumulative tributary inflow at site 9 was the same as that of the high error bar at site $10\left(1,840 \mathrm{ft}^{3} / \mathrm{s}\right)$. The cumulative tributary inflow was slightly higher after the input of site $19\left(1,890 \mathrm{ft}^{3} / \mathrm{s}\right)$ than the streamflow at site 20 high error bar $\left(1,870 \mathrm{ft}^{3} / \mathrm{s}\right)$ (fig. 4).
The method used for computing error from the ADCP measurements at sites 10 and 20 resulted in very small errors applied to those streamflows. Thus, this analysis may support a slight loss of flow from the main stem between site 10 of $20 \mathrm{ft}^{3} / \mathrm{s}\left(1,810 \mathrm{ft}^{3} / \mathrm{s}\right.$ at site 20 high error bar minus a cumulative $1,890 \mathrm{ft}^{3} / \mathrm{s}$ at site 9$)$ or about 1 percent of the flow at site 20 $\left(1,850 \mathrm{ft}^{3} / \mathrm{s}\right)$ (fig. 4).

\section{Results of Synoptic Selenium Concentration and Load Analysis}

Selenium concentrations and loads were used to identify locations of Se sources. Selenium concentrations in the Gunnison River (fig. 5, table 1) ranged from $1.4 \mu \mathrm{g} / \mathrm{L}$ at site 1 to $3.4 \mu \mathrm{g} / \mathrm{L}$ at site 20 within the study reach, indicating that Se concentrations increase from upstream to downstream. Concentrations increased slightly downstream to $3.7 \mu \mathrm{g} / \mathrm{L}$ at site 23 downstream of the study reach (table 2). The large inflow of higher concentration water from the Uncompahgre River (site 4, $11.2 \mu \mathrm{g} / \mathrm{L}$ ) increased the concentration in the Gunnison main stem. Although Se concentration was not sampled just below the confluence of the Gunnison and Uncompahgre Rivers, back-calculating concentration from the combined loads results in a computed concentration of $3.2 \mu \mathrm{g} / \mathrm{L}$ (table 1).

Selenium concentrations in tributaries ranged from $2.0 \mu \mathrm{g} / \mathrm{L}$ at site 19 to $284 \mu \mathrm{g} / \mathrm{L}$ at site 17 (Roubideau Creek at mouth near Delta and West unnamed drain at Escalante State Wildlife Area, respectively). Sites 15, 16, and 17, which drain ponds at the Escalante State Wildlife Area, had the three largest concentrations sampled during the synoptic sampling, 59.1, 69.5, and $284 \mu \mathrm{g} / \mathrm{L}$, respectively. The effluent from the Delta Sewage Treatment Plant (site 5) also enters the Gunnison River, and concentration and streamflow were $6.3 \mu \mathrm{g} / \mathrm{L}$ and $1.47 \mathrm{ft}^{3} / \mathrm{s}$ during the synoptic sampling (fig. 5, table 1). Error was described as the SD of the two replicate pairs and the 32 laboratory rerun analyses of Se concentrations, which was $2.3 \mu \mathrm{g} / \mathrm{L}$ (for the loading analysis, the error was stratified by concentration as described under the "Error Analysis" heading of this report).

The Se load in the Gunnison River at site 1, the most upstream main-stem site, was about 34 percent $(11.4 \mathrm{lb} / \mathrm{d})$ of the load at the furthest downstream synoptic sample location at site $20(33.4 \mathrm{lb} / \mathrm{d})$ (table 1 and fig. 2). The combined Se loads from Gunnison River at Delta (site 3) and Uncompahgre River at Delta (site 4) were about 95 percent of the load at the furthest downstream main-stem sample location at site $20(31.6 \mathrm{lb} / \mathrm{d}$ and $33.4 \mathrm{lb} / \mathrm{d}$, respectively, table 1$)$, indicating that about 5 percent of the total load was potentially contributed from diffuse groundwater inflow. The cumulative load from measured tributary inflows downstream from the Uncompahgre River confluence only amounted to an additional 1.2 pounds (lb) of additional load. This $1.2 \mathrm{lbs}$ from tributaries was only about 67 percent of the gain indicated from main-stem loads (1.8 lbs gain) from site 4 to the end of the synoptic reach at site 20 . The remaining 33 percent (about $0.6 \mathrm{lbs}$ ) of Se load increase was not accounted for by 


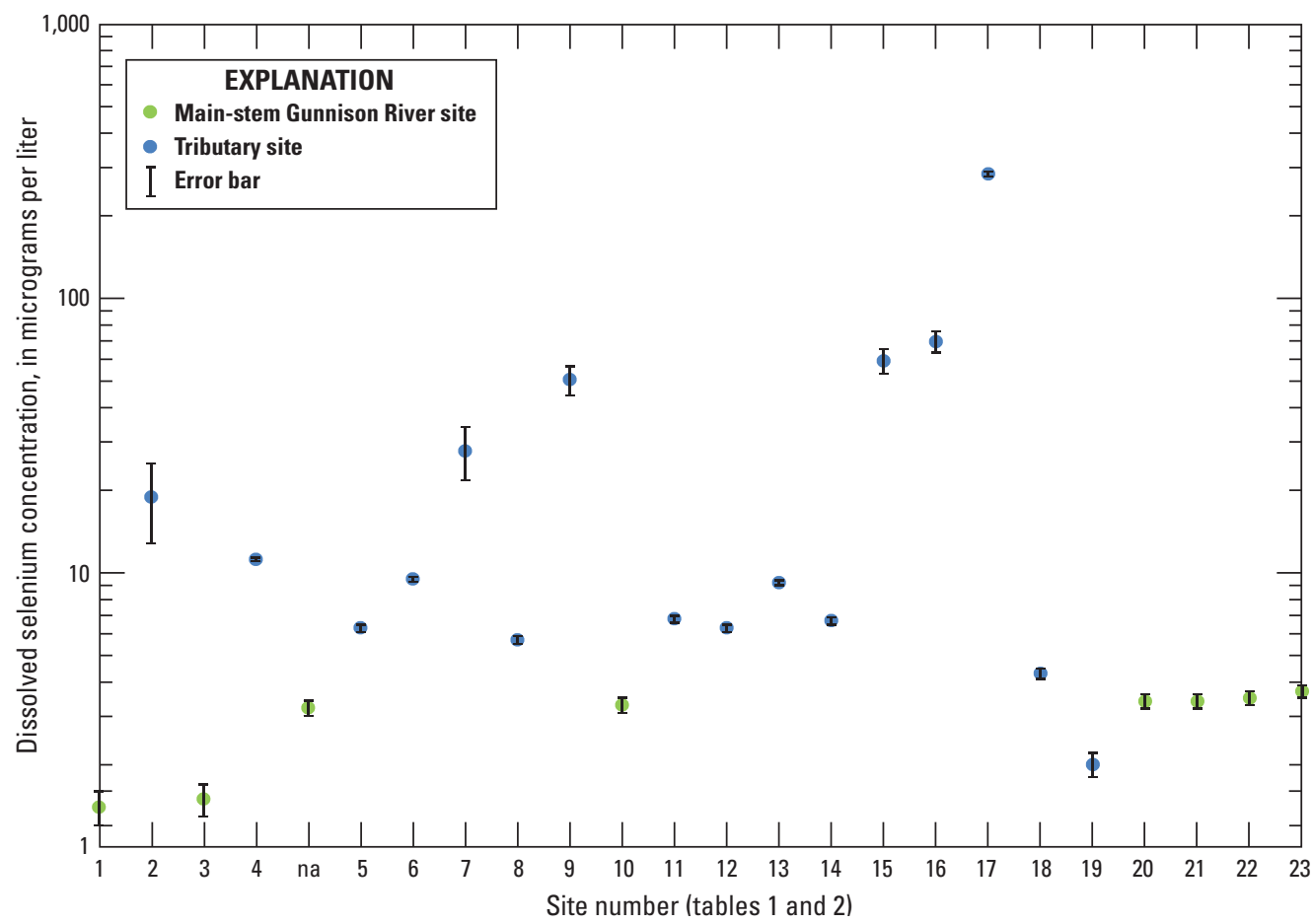

Figure 5. Dissolved selenium concentrations with error bars for tributaries and the mainstem Gunnison River (site numbers correspond to site numbers in tables 1 and 2).

known tributary inflow. Yet, the small changes in the streamflow mass balance in the same reach does not strongly support a net inflow explanation for the apparent gain in load.

Figure 6 indicates that Se load in the Gunnison River increased sharply from $12.2 \mathrm{lb} / \mathrm{d}$ at site 3 to $31.2 \mathrm{lb} / \mathrm{d}$ with inflowing load from the Uncompahgre River (site 4 was about 62 percent of the total combined load). Downstream from the confluence, values of Se load in the main-stem Gunnison increased slightly downstream to the last synoptic location on the main stem (site 20, Gunnison River below Roubideau Creek near Delta, fig. 2). As discussed previously, without taking potential error into consideration, cumulative loads from tributaries in the reach below the confluence (fig. 6) do not quite account for the increased loads in the main stem, indicating potential gain in Se load. This increase of $1.8 \mathrm{lbs}$ from the confluence of the Gunnison River and Uncompahgre River to site 20 at the end of the synoptic reach appears to be evidence that substantiates net load inputs of Se to the main stem from diffuse groundwater inflow. The increase in main-stem loads (fig. 6) downstream from the confluence with the Uncompahgre River necessitated an analysis of errors for an understanding of whether the differences in Se load were greater than the associated errors in main-stem loading. A loading error value was computed for each separate instantaneous load of Se on the main stem of the Gunnison River and ranged from 1.6 (site 1) to $3.7 \mathrm{lb} / \mathrm{d}$ (for the combined flows of sites 3 and 4 ) as a plus or minus error from the reported load (table 1). When errors associated with the main-stem loads are considered, the increase in loads in the lower part of the reach are still within the estimates of error (fig. 6). Error also was associated with the tributary loads between site 10 and site 20 not depicted on figure 6, but they are generally small (ranging from less than $0.001 \mathrm{lbs}$ at sites 14 and 15 , to $0.052 \mathrm{lbs}$ at site 19 (table 1). Because of the potential error in computed loading for the main stem, there does not seem to be enough certainty that unknown diffuse inflow contributes substantially to Se load in the synoptic reach on the day of sampling.

An initial hypothesis that would explain Se load gains to the Gunnison River between Delta and Grand Junction as diffuse groundwater was not confirmed in a load analysis of a selected reach between Delta and Gunnison River below Roubideau Creek near Delta. The study design would be particularly suited for identification of substantial groundwater contributions in the study reach for this report. The Se load that was unaccounted for in Reclamation (2006) and Henneberg (2016) may potentially be explained by six factors:

- This study only analyzed the reach between Delta and the Gunnison River below Roubideau Creek, which was the most likely reach to have diffuse groundwater inflows related to irrigation, and not the entire reach from Delta to Gunnison River near Grand Junction assessed in the previous reports.

- Previous reports did not account for tributary loads in the reach between Delta and Gunnison River near Grand Junction that may explain the Se load gains. 


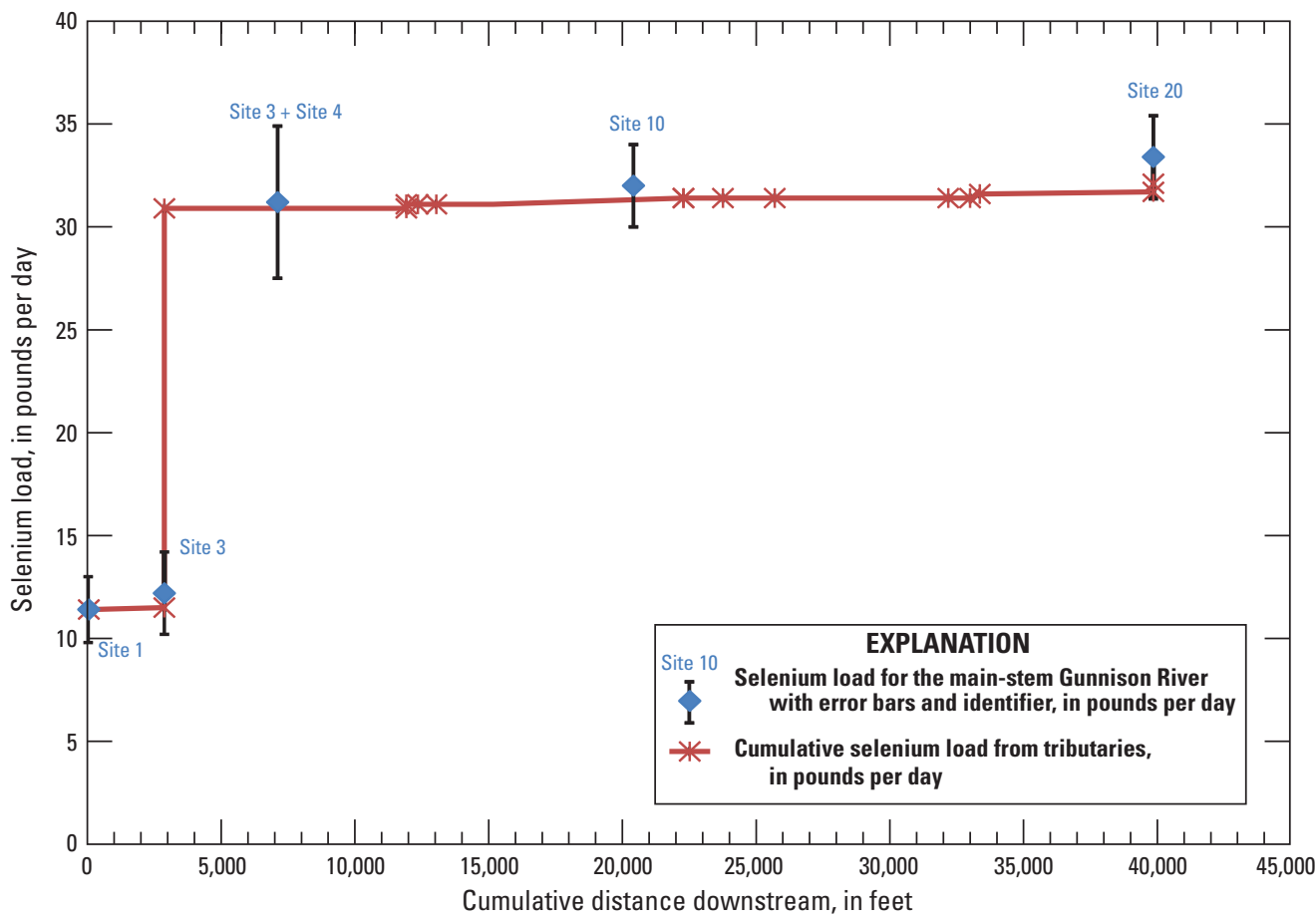

Figure 6. Main-stem Gunnison River dissolved selenium loads along the main-stem Gunnison River (in feet downstream from U.S. Highway 50 bridge at Delta, Colo.) with error bars corresponding to accuracy of the load values, and cumulative measured tributary loads to the main-stem Gunnison River.

- In this report, all synoptic measurements were taken with a single sampling protocol, consistent discharge measurement protocols, and a single analytical laboratory. Data available for the Reclamation (2006) report were compiled from many reports from 1988 to 1999 , and may have included more than one laboratory method and reporting limit, or measurement protocol, and were compiled from data that represented more than a single time period.

- For this report, measurements were taken on a single day during base flow when changes in flow were not expected and any diffuse-groundwater inflows might be most accurately assessed; whereas, Henneberg (2016) used continuous streamflow data and regression equations to compute annual loads and then compared 4-year sums from upstream to downstream. The load difference computed in previous studies also included loading occurring during nonstable streamflow conditions, making a direct comparison difficult.

- In this report, computations of loads included a cumulative error assessment, which qualified any differences in load according to errors estimated from Se laboratory analyses and methods of streamflow measurement used in the load calculations. Reclamation (2006) and Henneberg (2016) did not include an error assessment, so differences found in Reclamation (2006) may be the result of uncharacterized uncertainty.

\section{Implications}

Based on the results of the loading and streamflow analysis, when errors in the loading estimates are considered, there is no conclusive evidence of an appreciable amount of Se load that is unaccounted for in the study reach of the Gunnison River as was originally hypothesized. Whereas, literature sources and streamgage comparisons of the combined flows of the Gunnison and Uncompahgre Rivers (sum of CA1 through CA5) (fig. 1) seemed to indicate possible loading sources (17 to 19 percent) in the synoptic reach (Henneberg, 2016; Reclamation, 2006). Differences determined from comparisons of cumulative tributary loads and Gunnison River main-stem loads for this study are within error estimates of the main-stem loads. Main-stem streamflow accounting during November 2015 in a downstream direction also was not supportive of substantial net gains or losses in the main-stem water balance. Note, however, that the Gunnison River synoptic reach in this study does not include the reach from site 20 (Gunnison River below Roubideau Creek near Delta) to site 23 (Gunnison River near Grand Junction). Additional Gunnison River sites (21 and 22) that were sampled downstream from the study reach indicate the possibility of additional Se load contributed downstream from site 20 (table 2). Whether this is diffuse groundwater input or surface-water inputs from several tributaries cannot be ascertained from this study because these possible surface-water sources were not identified and 
sampled, as they were beyond the scope of this study. The reach for this study was hypothesized to be the most probable source for diffuse groundwater inputs because it drains the main agricultural area downstream from the confluence of the Gunnison and Uncompahgre Rivers. The reach of the Gunnison River downstream from Roubideau Creek to site 23 (09152500) has few irrigated lands (fig. 1). Although upstream loading not accounted for at site 23 (Gunnison River near Grand Junction) noted from previous studies may have sources downstream from this study reach, it may be an artifact of errors (uncertainty of methods) in previous measurements and estimates, or data may have been collected during less stable flow conditions.

\section{Summary}

In 2013, the U.S. Bureau of Reclamation established the Selenium Management Program for the Lower Gunnison River Basin in response to a Programmatic Biological Opinion issued by the U.S. Fish and Wildlife Service. The Selenium Management Program, consisting of Federal, State, and local agencies as well as local water users, seeks to identify and mitigate selenium (Se) sources to decrease Se levels in endangered fish habitat in the Gunnison River and its tributaries. Prior to this study, Se loading data collected at U.S. Geological Survey streamflow gages during water years 2011 to 2014 accounted for about 81 percent of the Se load at Gunnison River near Grand Junction. This analysis did not include an assessment of load contributions from surfacewater tributaries to the Gunnison River below Roubideau Creek near Delta. As a result of the loading estimates that indicated a potential missing part of the Se load, the Selenium Management Plan indicated a need to investigate a reach of the Gunnison River near Delta, Colo., which was suspected to be a source of Se load, but had not been quantified.

In response to the need for more information about Se sources and transport, the U.S. Geological Survey, in cooperation with the Colorado Water Conservation Board, completed a study that characterized Se loads in a reach of the Gunnison River between Delta and Grand Junction. The purpose of this report is to identify where possible dissolved Se loading is occurring in a study reach in the Lower Gunnison River Basin between Delta and Grand Junction. This report documents the methods and results of the synoptic sampling completed on this reach on November 19, 2015. Three additional main-stem Gunnison River sites downstream from the synoptic reach also were sampled to provide supplementary information. An included assessment of error also was important for interpretation of synoptic results because uncertainty in streamflow measurements and waterquality analytical methods may be larger than the differences in load observed in the analysis.

The combined Se loads from Gunnison River at Delta (site 3) and Uncompahgre River at Delta (site 4) were about 95 percent of the load at the furthest downstream main-stem sample location at site 20 (31.6 pounds per day [lb/d] and $33.4 \mathrm{lb} / \mathrm{d}$, respectively, table 1 ), indicating that about 5 percent of the total load was potentially contributed from diffuse groundwater inflow.

The cumulative load from measured tributary inflows downstream from the Uncompahgre River confluence only amounted to $1.2 \mathrm{lbs}$ of additional load. This $1.2 \mathrm{lbs}$ from tributaries was only about 67 percent of the gain indicated from main-stem loads (1.8 lbs gain) from site 4 to the end of the synoptic reach at site 20 . The remaining 33 percent (about $0.6 \mathrm{lbs}$ ) of Se load increase was not accounted for by known tributary inflow. Yet, the small changes in the streamflow mass balance in the same reach does not strongly support a net inflow explanation for the apparent gain in load.

A loading error value was computed for each separate instantaneous load of Se on the main stem of the Gunnison River and ranged from 1.6 (site 1 ) to $3.7 \mathrm{lb} / \mathrm{d}$ (for the combined flows of sites 3 and 4) as a plus or minus error from the reported load. Based on the results of the loading and streamflow analysis, when errors in the loading estimates are considered, there is no conclusive evidence of an appreciable amount of Se load that is unaccounted for in the study reach of the Gunnison River as was originally hypothesized. Differences determined from comparisons of cumulative tributary loads and Gunnison River main-stem loads for this study are within error estimates of the main-stem loads.

Main-stem streamflow accounting during November 2015 in a downstream direction also was not supportive of substantial net gains or losses in the main-stem water balance. The reach for this study was hypothesized to be the most probable source for diffuse groundwater inputs because it drains the main agricultural area downstream from the confluence of the Gunnison and Uncompahgre Rivers. The reach of the Gunnison River downstream from Roubideau Creek near Delta to site 23 has few irrigated lands. Although upstream loading not accounted for at site 23 (Gunnison River near Grand Junction) noted from previous studies may have sources downstream from this study reach, it may be an artifact of errors (uncertainty of methods) in previous measurements and estimates, or data may have been collected during less stableflow conditions. 


\section{Acknowledgments}

The authors are appreciative of peer reviews by Carleton Bern and Rob Runkel.

\section{References Cited}

Bevington, B.R., and Robinson, D.K., 2003, Data reduction and error analysis for the physical sciences: New York, McGraw-Hill, 320 p.

Bossong, C.R., Caine, J.S., Stannard, D.I., Flynn, J.L., Stevens, M.R., and Heiny-Dash, J.S., 2006, Hydrologic conditions and assessment of water resources in the Turkey Creek watershed, Jefferson County, Colorado,1998-2001: U.S. Geological Survey Water-Resources Investigations Report 03-4034, 140 p.

Brenton, R.W., and Arnett, T.L., 1993, Methods of analysis by the U.S. Geological Survey National Water Quality Laboratory-Determination of dissolved organic carbon by UV-promoted persulfate oxidation and infrared spectrometry: U.S. Geological Survey Open-File Report 92-480, 12 p.

Bureau of Reclamation [Reclamation], 2006, Evaluation of selenium remediation concepts for the Lower Gunnison and Lower Uncompahgre Rivers, Colorado: Prepared by the National Irrigation Water Quality Program and Reclamation's Technical Assistance to States Program in conjunction with the Gunnison Basin Selenium Task Force, July 2006, 49 p.

Bureau of Reclamation [Reclamation], 2014, Selenium management program, Gunnison River Basin, Colorado, Annual progress report 2014: Prepared by the Selenium Management Program Workgroup in Bureau of Reclamation 2014 Annual Reports under the Gunnison River Programmatic Biological Opinion-Aspinall Unit, Dolores Project, and Selenium Management Program, January 2015, 22 p.

Butler, D.L., 2001, Effects of piping irrigation laterals on selenium and salt loads, Montrose Arroyo Basin, western Colorado: U.S. Geological Survey Water-Resources Investigations Report 01-4024, 14 p.

Butler, D.L., Krueger, R.P., Osmundson, B.C., Thompson, A.L., and McCall, S.K., 1991, Reconnaissance investigation of water quality, bottom sediment, and biota associated with irrigation drainage in the Gunnison and Uncompahgre River Basins and at Sweitzer Lake, west-central Colorado, 1988-1989: U.S. Geological Survey Water-Resources Investigations Report 91-4103, 99 p.

Butler, D.L., Wright, W.G., Stewart, K.C., Osmundson, B.C., Krueger, R.P., and Crabtree, D.W., 1996, Detailed study of selenium and other constituents in water, bottom sediment, soil, alfalfa, and biota associated with irrigation drainage in the Uncompahgre Project Area and in the Grand Valley, west-central Colorado, 1991-1993: U.S. Geological Survey Water-Resources Investigations Report 96-4138, 136 p.

Evangelou, V.P., Whittig, L.D., and Tanji, K.K., 1984, Dissolved mineral salts derived from Mancos Shale: Journal of Environmental Quality, v. 13, no. 1, p. 146-150.

Fishman, M.J., ed., 1993, Methods of analysis by the U.S. Geological Survey National Water Quality LaboratoryDetermination of inorganic and organic constituents in water and fluvial sediments: U.S. Geological Survey OpenFile Report 93-125, 217 p.

Fishman, M.J., and Friedman, L.C., 1989, Methods for determination of inorganic substances in water and fluvial sediments: U.S. Geological Survey Techniques of WaterResources Investigations, book 5, chap. A1, 545 p.

Garbarino, J.R., 1999, Methods of analysis by the U.S. Geological Survey National Water Quality LaboratoryDetermination of dissolved arsenic, boron, lithium, selenium, strontium, thallium, and vanadium using inductively coupled plasma-mass spectrometry: U.S. Geological Survey Open-File Report 99-093, 31 p.

Garbarino, J.R., Kanagy, L.K., and Cree, M.E., 2006, Determination of elements in natural-water, biota, sediment, and soil samples using collision/reaction cell inductively coupled plasma-mass spectrometry: U.S. Geological Survey Techniques and Methods, book 5, sec. B, chap. 1, 88 p.

Hem, J.D., 1985, Study and interpretation of chemical characteristics of natural water (3d ed.): U.S. Geological Survey Water-Supply Paper 2254, 264 p.

Henneberg, M.F., 2016, 2014 annual summary of the lower Gunnison River Basin Selenium Management Program water-quality monitoring, Colorado: U.S. Geological Survey Open-File Report 2016-1129, 25 p., https://doi.org/10.3133/ ofr20161129.

Leib, K.J., 2008, Concentrations and loads of selenium in selected tributaries to the Colorado River in the Grand Valley, western Colorado, 2004-2006: U.S. Geological Survey Scientific Investigations Report 2008-5036, 36 p.

Leib, K.J., Linard, J.I., and Williams, C.A., 2012, Statistical relations of salt and selenium loads to geospatial characteristics of corresponding subbasins of the Colorado and Gunnison Rivers in Colorado: U.S. Geological Survey Scientific Investigations Report 2012-5003, 31 p.

Mast, M.A., Mills, T.J., Paschke, S.S., Keith, G., and Linard, J.I., 2014, Mobilization of selenium from the Mancos Shale and associated soils in the Lower Uncompahgre River Basin, Colorado: Applied Geochemistry, v. 48, p. 16-27.

Moore, J.L., 2011, Characterization of salinity and selenium loading and land-use change in Montrose Arroyo, western Colorado, from 1992 to 2010: U.S. Geological Survey Scientific Investigations Report 2011-5106, 23 p. 
Mueller, D.S., Wagner, C.R., Rehmel, M.S., Oberg, K.A., and Rainville, Francois, 2013, Measuring discharge with acoustic Doppler current profilers from a moving boat (ver. 2.0, December 2013): U.S. Geological Survey Techniques and Methods, book 3, chap. A22, 95 p., https://doi.org/10.3133/ tm3A22.

Novak, C.E., 1985, WRD data reports preparation guide: U.S. Geological Survey Open-File Report 85-480, 199 p.

Patton, C.J., and Kryskalla, J.R., 2003, Methods of analysis by the U.S. Geological Survey National Water Quality Laboratory-Evaluation of alkaline persulfate digestion as an alternative to Kjeldahl digestion for determination of total and dissolved nitrogen and phosphorus in water: U.S. Geological Survey Water-Resources Investigations Report 2003-4174, 33 p.

Patton, C.J., and Kryskalla, J.R., 2011, Colorimetric determination of nitrate plus nitrite in water by enzymatic reduction, automated discrete analyzer methods: U.S. Geological Survey Techniques and Methods, book 5, chap. B8, 34 p.

Turnipseed, D.P., and Sauer, V.B., 2010, Discharge measurements at gaging stations: U.S. Geological Survey Techniques and Methods, book 3, chap. A8, 87 p., accessed May 18, 2017, at https://pubs.usgs.gov/tm/tm3-a8/.

Tuttle, M.L.W., Fahy, J.W., Elliott, J.G., Grauch, R.I., and Stillings, L.L., 2014, Contaminants from cretaceous black shale: II. Effect of geology, weathering, climate, and land use on salinity and selenium cycling, Mancos Shale landscapes, southwestern United States: Applied Geochemistry, v. 46, p. $72-84$.
Tuttle, M.L., and Grauch, R.I., 2009, Salinization of the upper Colorado River-Fingerprinting geologic salt sources: U.S. Geological Survey Scientific Investigations Report 2009-5072, 62 p.

U.S. Fish and Wildlife Service [USFWS], 2009, Final Gunnison River Basin programmatic biological opinion: ES/ GJ-6-CO-09-F-0001 TAILS 65413-2009-F-0044, 123 p., accessed August 5, 2015, at https://www.usbr.gov/uc/wcao/ $\mathrm{rm} /$ aspeis/pdfs/aspinallpbo_final.pdf.

U.S. Geological Survey [USGS], variously dated, National field manual for the collection of water-quality data: U.S. Geological Survey Techniques of Water-Resources Investigations, book 9, chaps. A1-A10, accessed May 2017, at https://pubs.water.usgs.gov/twri9A.

U.S. Geological Survey, 2016, National Water Information System - Web interface, accessed February 11, 2018, at https://doi.org/10.5066/F7P55KJN

Williams, C.A., and Leib, K.J., 2005, Using tracers to evaluate streamflow gain-loss characteristics of Terror Creek, in the vicinity of a mine-permit area, Delta County, Colorado, water year 2003: U.S. Geological Survey Scientific Investigations Report 2005-5018, 27 p.

Zivot, E., and Wang, J., 2006, Modeling financial time series with S-PLUS: New York, Springer-Verlag, 998 p., accessed October 24, 2017, at http://www.springer.com/978-0-38727965-7.
Publishing support provided by the Science Publishing Network, Denver Publishing Service Center

For more information concerning the research in this report, contact the Director, USGS Colorado Water Science Center Box 25046, Mail Stop 415

Denver, CO 80225

(303) 236-4882

Or visit the Colorado Water Science Center website at https://co.water.usgs.gov/ 
